The research program of the Center for Economic Studies (CES) produces a wide range of theoretical and empirical economic analyses that serve to improve the statistical programs of the U.S. Bureau of the Census. Many of these analyses take the form of CES research papers. The papers are intended to make the results of CES research available to economists and other interested parties in order to encourage discussion and obtain suggestions for revision before publication. The papers are unofficial and have not undergone the review accorded official census Bureau publications. The opinions and conclusions expressed in the papers are those of the authors and do not necessarily represent those of the U.S. Bureau of the Census. Republication in whole or part must be cleared with the authors.

IMMIGRATION, SKILL MIX, AND THE CHOICE OF TECHNIQUE

by

Ethan Lewis *
Federal Reserve Bank of Philadelphia

CES 05-04 May, 2005

All papers are screened to ensure that they do not disclose confidential information. Persons who wish to obtain a copy of the paper, submit comments about the paper, or obtain general information about the series should contact Sang $V$. Nguyen, Editor, Discussion Papers, Center for Economic Studies, Washington Plaza II, Room 206, Bureau of the Census, Washington, DC 20233-6300, (301-763-1882) or INTERNET address snguyen@ces.census.gov. 


\title{
Immigration, Skill Mix, and the Choice of Technique *
}

\author{
Ethan Lewis \\ Federal Reserve Bank of Philadelphia ${ }^{* *}$
}

May 10, 2005

\footnotetext{
* I am grateful for the valuable feedback I received on this work from Clair Brown, Benjamin Campbell, David Card, Elizabeth Cascio, Andrew Hildreth, Shawn Kantor, Belinda Reyes, Albert Saiz, and seminar participants at the Philadelphia Federal Reserve Bank, the University of Maryland, the San Francisco Federal Reserve Bank, and Drexel University. Shannon Mail provided excellent research assistance. I alone am responsible for any errors. ** The views expressed here are those of the author and do not necessarily reflect the views of the Federal Reserve Bank of Philadelphia or the Federal Reserve System.
} 


\title{
Immigration, Skill Mix, and the Choice of Technique
}

\begin{abstract}
Using detailed plant-level data from the 1988 and 1993 Surveys of Manufacturing Technology, this paper examines the impact of skill mix in U.S. local labor markets on the use and adoption of automation technologies in manufacturing. The level of automation differs widely across U.S. metropolitan areas. In both 1988 and 1993, in markets with a higher relative availability of lessskilled labor, comparable plants - even plants in the same narrow (4-digit SIC) industries - used systematically less automation. Moreover, between 1988 and 1993 plants in areas experiencing faster less-skilled relative labor supply growth adopted automation technology more slowly, both overall and relative to expectations, and even de-adoption was not uncommon. This relationship is stronger when examining an arguably exogenous component of local less-skilled labor supply derived from historical regional settlement patterns of immigrants from different parts of the world.

These results have implications for two long-standing puzzles in economics. First, they potentially explain why research has repeatedly found that immigration has little impact on the wages of competing native-born workers at the local level. It might be that the technologies of local firms - rather than the wages that they offer-respond to changes in local skill mix associated with immigration. A modified two-sector model demonstrates this theoretical possibility. Second, the results raise doubts about the extent to which the spread of new technologies have raised demand for skills, one frequently forwarded hypothesis for the cause of rising wage inequality in the United States. Causality appears to at least partly run in the opposite direction, where skill supply drive s the spread of skill-complementary technology.
\end{abstract}

JEL: J2, F1, O3

Keywords: Technological change, immigration, local labor market 
Much has been written about how advances in technology advance have raised the skill requirements in the U.S. labor market. Evidence of "skill-biased technological change" has been found in the association between the use of technology and the relative employment and wages of skilled workers when looking across workers (e.g. Krueger (1993)), plants (e.g. Dunne et al. (2004)), and industries (e.g. Autor, Levy, and Murnane (2003)). It is also argued that the supply of skills has not kept pace with demand, leading to a growing gap between the earnings of skilled and unskilled workers (e.g. Katz and Murphy (1994)).

At the same time, however, the U.S. is in the midst of an immigration boom which has raised the proportion of workers who are less-skilled, particularly in certain parts of the U.S. Since 1970, immigrants have risen from 5 to 15 percent of the U.S. workforce. 40 percent of immigrants have less than a high school education compared to 10 percent of native-born Americans. Furthermore, the impact of this boom has been geographically uneven: immigrants are highly concentrated in particular labor markets, and the proportion of the workforce which is less-skilled is higher in more immigrant-dense markets. Yet study after study has found that the local labor market impact of immigration on the relative employment rates and wages of lessskilled workers is almost zero. ${ }^{1}$ High-immigration markets have succeeded in productively employing large numbers of unskilled workers, despite the supposedly increased demand for skilled labor that the diffusion of new technologies has generated. How is this possible?

One way markets may be able to absorb less-skilled immigrants is by adopting less of the new high-skill technologies. ${ }^{2}$ The expectation that the local labor market impact of immigration

\footnotetext{
${ }^{1}$ Borjas (1994) and Friedberg and Hunt (1995) provide reviews of this literature. Note that this is also despite evidence in other contexts that labor supply has an impact on wages (Hamermesh (1993)), including evidence that immigration has an impact at the national level (Borjas (2003)).

${ }^{2}$ Another explanation, discussed further below, is that local markets in the U.S. are each a small part of a large and integrated national economy, so factor prices are insensitive to local factor mix. Lewis (2004b) found specialization in 3-digit industries to be unimportant, absorbing at most 10 percent of immigrant-induced skill mix differences
} 
ought to be large derives from a standard view that production technology is invariant to input availability. Recent models of innovation (Acemoglu (1998)) and technology choice (Beaudry and Green $(2000,2003))$ demonstrate that technology may adjust to skill mix, and that the adjustment of technology mitigates the usual effect of labor supply on wages. Below I present a modified version of Beaudry and Green (2000) which shows how a local market can adapt to an influx of less-skilled workers by using less of a skill-intensive technique, allowing the new immigrants to be employed at existing less-skilled wages. The idea that employers adapt technology to input availability is not new (see, e.g., Solow (1962), Johansen (1959), Habbakkuk (1962)) but it conflicts with the "conventional" view implied by recent studies that treat technology differences across plants or industries as exogenous in order to investigate the ir impact on wages or skill mix (Dunne et. al. (2004), Autor, Levy, and Murnane (2003)).

This paper evaluates the extent to which producers adapt technology to local input supplies using detailed data from the 1988 and 1993 Surveys of Manufacturing Technology (SMTs) on the use of automation technologies introduced into manufacturing in the past few decades (see Table 1). As with other recent technological advances, new plant automation techniques were projected to increase the relative employment of skilled workers, or as one study put it, “...jobs eliminated are semi-skilled or unskilled, while jobs created require significant technical background" (Hunt and Hunt (1983), p. xii). Doms, Dunne, and Troske (1997) used the SMT data to show that more automated plants do indeed have a higher skilled employment share. They also showed, however, that the same plants had a higher skill share well before they 
adopted the new technology. ${ }^{3}$ Given this, it is appropriate to ask the extent to which causality runs from skills to technology, rather than the reverse. Manufacturing automation is particularly suited to evaluate the impact of immigration because less-skilled workers in SMT-covered industries, especially immigrants, are concentrated in labor-intensive assembly, welding, and other tasks that these technologies replace (See Table 3).

Technology data are supplemented with labor force data from Current Population Surveys and Censuses of Population. The combined data show that, in two separate crosssections, the higher the relative number of workers who were high school dropouts in a metropolitan area, the less automated the plants in the area were. In addition, between 1988 and 1993, plants' use of technology grew more slowly, both overall and relative to forecasts where the relative number of dropouts in the local work force grew more quickly. Instrumental variables estimates, based on historical less-skilled immigration patterns, show that, if anything, simple least-squares correlations understate the impact of skill supply on the use of technology. A typical estimate is that a 10 percentage point (one standard deviation) increase in the lessskilled relative supply reduces the technology use at a typical worker's plant by roughly 0.5 technologies on a base of 6 technologies. So the impact of skill supply is substantial.

These results provide a potential explanation for why the local labor market impact of immigration is small. The modified version of Beaudry and Green (2000) I present below reduces essentially to a two-sector open-economy model, in which, as in the original, an increase in less-skilled relative supply does not affect relative wages in the long run. ${ }^{4}$ The difference from the original model is that the economy adjusts to the change in input mix not by changing

\footnotetext{
${ }^{3}$ On top of this, Luque and Miranda (2005) have used a match of unemployment insurance records to the SMT data to show that the higher average wages paid to workers at technologically-intensive plants can be attributed to firm and worker unobservables rather than the effect of technology.

${ }^{4}$ Provided that the change is not so large as to move the economy outside its "cone of diversification."
} 
the mix of goods produced, but rather by changing the mix of technologies used to produce the same goods. An alternative interpretation of the empirical results - that the observed response of "technology" to immigration is in fact due a shift to in industrial mix toward less-skilled intensive industries that also use less technology - cannot be completely ruled out. Inconsistent with this alternative interpretation, however, controls for narrow (four-digit SIC) industry, and within tho se controls for product "quality" (similar to Schott (2004)), have little impact on the strength of the relationship.

\section{Theory}

The idea that plants adjust technology to input availability is not new. This was a feature of "putty-clay" models (Solow (1962), Johansen (1959)) and was the core hypothesis of Habbakkuk's (1962) investigation of why the U.S. mechanized production ahead of the British in the nineteenth century. However, this idea fell out of favor until it recently re-emerged in models attempting to explain why recent technological advance in the U.S. is "skill-biased." Models of directed technical change (Acemoglu (1998)) and endogenous technology choice (Beaudry and Green $(2000,2003)$ ) argue in essence that skill-complementary technologies have become more prevalent as a result of the rising skills of the U.S. workforce. Acemoglu models innovation while Beaudry and Green model the choice among available technologies. In Beaudry and Green's model, firms choose between two technologies of high ("modern") and low ("traditional") skill-intensity. An immigration shock which raises the relative less-skilled labor induces firms to adopt less modern technology.

A version of Beaudry and Green's model, modified to be appropriate for a local labor market, can be used to show how local labor markets might adapt to less-skilled immigration in a 
way that affects technology but not relative wages. The key change from their model is to make the supply of capital elastic. Beaudry and Green model the supply of capital as fixed, an assumption that is potentially appropriate for a large national economy but seems unrealistic for a local labor market. ${ }^{5}$ As will be seen below, this change reduces the model to essentially a twosector Heckscher-Ohlin model, where the goods of different factor intensities have been relabeled as "technologies" of different factor intensities.

To illustrate a simple case of the model, suppose that perfectly competitive producers have available to them modern and traditional technologies which can each be represented by a Cobb-Douglass production function: ${ }^{6}$

$Y_{J}=A_{J} L_{J}^{\alpha_{J}} H_{J}^{\left(1-\alpha_{J}\right) \beta_{J}} K_{J}^{\left(1-\alpha_{J}\right)\left(1-\beta_{J}\right)}$

where $\mathrm{J} \in\{\mathrm{T}, \mathrm{M}\}$ indexes the "traditional" $(\mathrm{T})$ and "modern" (M) technologies; $\mathrm{L}_{\mathrm{J}}$ represents less-skilled labor, $\mathrm{H}_{\mathrm{J}}$ represents skilled labor, $\mathrm{K}_{\mathrm{J}}$ represents capital used in technology $\mathrm{J}$; and $\alpha_{\mathrm{J}}$, $\beta_{\mathrm{J}}$, and $\mathrm{A}_{\mathrm{J}}$ are parameters with $0<\alpha_{\mathrm{J}}, \beta_{\mathrm{J}}<1 \forall \mathrm{J}$. Beaudry and Green's assumptions can be represented as restrictions on $\alpha_{\mathrm{J}}$ and $\beta_{\mathrm{J}}$. The only assumption critical for my purpose, however, is that the modern technology is relatively skill-intensive:

$$
\frac{\left(1-\alpha_{M}\right) \beta_{M}}{\alpha_{M}}>\frac{\left(1-\alpha_{T}\right) \beta_{T}}{\alpha_{T}}
$$

\footnotetext{
${ }^{5}$ Theoretical investigations of the local labor market impact of immigration typically assume the supply of capital is elastic.

${ }^{6}$ A Cobb-Douglass technology implies an elasticity of substitution between skilled an unskilled labor (one) which is not that different than estimates (e.g. Hamermesh (1993)). This choice of technology serves only the purpose of simple illustration, however. The results hold for any constant returns to scale technology in which one technology is relatively skill intensive.
} 
It is also important to emphasize that the outputs of the two technologies $Y_{T}$ and $Y_{M}$ are perfect substitutes - there is only a single good. The price of the good is normalized to 1 .

The producer's problem can be solved by computing the minimum cost of producing a unit of output with each technology, given factor prices. Let $\mathrm{w}_{\mathrm{L}}, \mathrm{w}_{\mathrm{H}}$, and $\mathrm{r}$ represent factor prices for less-skilled labor, skilled labor, and capital, respectively. The unit cost functions are:

(1) $C^{J}\left(w_{L}, w_{H}, r\right)=c_{J} w_{L}^{\alpha_{J}} w_{H}^{\left(1-\alpha_{J}\right) \beta_{J}} r^{\left(1-\alpha_{J}\right)\left(1-\beta_{J}\right)}$ for $\mathrm{J} \in\{\mathrm{T}, \mathrm{M}\}$

where $c_{J}=A_{J}^{-1} \alpha_{J}{ }^{-\alpha_{J}}\left[\left(1-\alpha_{J}\right) \beta_{J}\right]^{-\left(1-\alpha_{J}\right) \beta_{J}}\left[\left(1-\alpha_{J}\right)\left(1-\beta_{J}\right)\right]^{-\left(1-\alpha_{J}\right)\left(1-\beta_{J}\right)}$ for $\mathrm{J} \in\{\mathrm{T}, \mathrm{M}\}$. If both methods are in use (the economy is inside the "cone of diversification"), perfect competition implies $\mathrm{C}^{\mathrm{M}}(\cdot)=\mathrm{C}^{\mathrm{T}}(\cdot)=1$, (zero profits - recall that the normalized output price is one). In keeping with the elastic capital supply assumption, $\mathrm{r}$ is assumed to be exogenous. Solving for $\mathrm{w}_{\mathrm{L}}$ and $w_{H}$ in terms of $r$ :

(2) $w_{L}=c_{T}^{\frac{\left(1-\alpha_{M}\right) \beta_{M}}{\alpha_{M}\left(1-\alpha_{T}\right) \beta_{T}-\alpha_{T}\left(1-\alpha_{M}\right) \beta_{M}}} c_{M}^{-\frac{\left(1-\alpha_{T}\right) \beta_{T}}{\alpha_{M}\left(1-\alpha_{T}\right) \beta_{T}-\alpha_{T}\left(1-\alpha_{M}\right) \beta_{M}}} r^{\frac{\left(1-\alpha_{M}\right)\left(1-\alpha_{T}\right)\left[\beta_{M}\left(1-\beta_{T}\right)-\beta_{T}\left(1-\beta_{M}\right)\right]}{\alpha_{M}\left(1-\alpha_{T}\right) \beta_{T}-\alpha_{T}\left(1-\alpha_{M}\right) \beta_{M}}} \equiv w_{L}(r)$

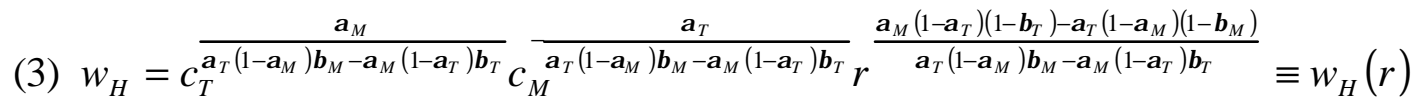

(2) and (3) show that changes in the relative supply of skilled and unskilled labor have no effect on wages inside the cone of diversification: factor supplies do not appear in (2) and (3). This is the usual "factor price insensitivity" result of the two-sector model (Leamer (1995)). It is depicted graphically in Figure 1, which shows unit isoquants of the modern and traditional 
methods in $(\mathrm{H}, \mathrm{L})$ space. The modern isoquant is up and to the left of the traditional one, indicating its greater skill-intensity. At any endowment point inside the cone delimited by the expansion paths of these two technologies - such as $(\mathrm{H}, \mathrm{L})$ shown in Figure 1 - relative wages are constant at the level implied by the tangent unit isocost line $1 / \mathrm{w}_{\mathrm{H}}(\mathrm{r})$ to $1 / \mathrm{w}_{\mathrm{L}}(\mathrm{r})$. Full employment is achieved by producing with a linear combination of modern and traditional methods, as indicated by the vectors leading to $(\mathrm{H}, \mathrm{L})$.

Figure 1 also shows that an increase in the relative supply of less-skilled labor reduces relative use of the modern method, i.e. the "Rybczynski theorem." An influx of less-skilled immigrants which moves the input endowment to $\left(\mathrm{H}, \mathrm{L}^{\prime}\right)$, for example, results in a decrease in the output of modern method and an increase in the output of the traditional method. This can also be demonstrated mathematically by solving labor market clearing conditions. Let $\mathrm{H}$ and $\mathrm{L}$ represent the exogenously determined supplies of high- and less-skilled labor. By Shephard's Lemma the vector of factor demands equals the gradient of the cost function, so from (1):

$$
\begin{aligned}
L_{J} & =Y_{J} C_{1}^{J}\left(w_{L}, w_{H}, r\right)=Y_{J} \alpha_{J} c_{J} w_{L}^{\alpha_{J}-1} w_{H}^{\left(1-\alpha_{J}\right) \beta_{J}} r^{\left(1-\alpha_{J}\right)\left(1-\beta_{J}\right)} \\
& =Y_{J} \alpha_{J} C^{J}\left(w_{L}, w_{H}, r\right) / w_{L} \\
& =Y_{J} \alpha_{J} / w_{L}
\end{aligned}
$$

for $\mathrm{J} \in\{\mathrm{T}, \mathrm{M}\}$, where the last step follows from zero profits. Similarly:

$$
H_{J}=Y_{J}\left(1-\alpha_{J}\right) \beta_{J} / w_{H}
$$

for $\mathrm{J} \in\{\mathrm{T}, \mathrm{M}\}$. Substituting these into labor market clearing conditions, $\mathrm{H}=\mathrm{H}_{\mathrm{T}}+\mathrm{H}_{\mathrm{M}}$ and $\mathrm{L}=\mathrm{L}_{\mathrm{T}}$ $+\mathrm{L}_{\mathrm{M}}$, produces, in matrix notation: 


$$
\left[\begin{array}{cc}
\alpha_{T} / w_{L} & \alpha_{M} / w_{L} \\
\left(1-\alpha_{T}\right) \beta_{T} / w_{H} & \left(1-\alpha_{M}\right) \beta_{M} / w_{H}
\end{array}\right]\left[\begin{array}{c}
Y_{T} \\
Y_{M}
\end{array}\right]=\left[\begin{array}{c}
L \\
H
\end{array}\right]
$$

Let $D \equiv\left[\begin{array}{ll}d_{L T} & d_{L M} \\ d_{H T} & d_{H M}\end{array}\right]$ denote the matrix above, whose elements are each positive. Then, $Y_{M}=|D|^{-1}\left(d_{L T} H-d_{H T} L\right)$ depends negatively on the relative supply of less-skilled labor so long as $|D|>0$. But this is equivalent to the condition $\alpha_{T}\left(1-\alpha_{M}\right) \beta_{M}>\alpha_{M}\left(1-\alpha_{T}\right) \beta_{T}$ which follows from the assumption that the modern technology is relatively skill-intensive. Similarly, $\mathrm{Y}_{\mathrm{T}}$ depends positively on the relative supply of less-skilled labor. Thus the relative use of the modern method falls with an increase in less-skilled relative labor supply, as we wanted. It also follows that the use of modern machinery, $\mathrm{K}_{\mathrm{M}}$, falls as less-skilled relative supply increases, which is the implication tested below. ${ }^{7}$ The inessentiality of the Cobb-Douglass functional form should also be evident. ${ }^{8}$

Though not necessary for the result above, an interesting and realistic case is one in which the modern method is also relatively capital-intensive:

$\left(1-\alpha_{M}\right)\left(1-\beta_{M}\right)>\left(1-\alpha_{T}\right)\left(1-\beta_{T}\right)$

${ }^{7}$ A final loose end is to show that the cone of diversification exists, i.e, that $Y_{M}$ and $Y_{T}$ can be both simultaneously greater than zero. The required condition is:

$\frac{\alpha_{T}}{\left(1-\alpha_{T}\right) \beta_{T}}>\frac{w_{L} L}{w_{H} H}>\frac{\alpha_{M}}{\left(1-\alpha_{M}\right) \beta_{M}}$

This outcome is feasible under the model's assumption that the modern method is relatively skill-intensive.

${ }^{8}$ The assumption $\frac{C_{1}^{T}(\cdot)}{C_{2}^{T}(\cdot)}>\frac{C_{1}^{M}(.)}{C_{2}^{M}(\cdot)}$ (for constant any constant returns to scale technology) is sufficient to obtain these results. This is an assumption that Beaudry and Green (2000) make. 
Under this assumption, an increase in less-skilled relative labor supply also causes the capital intensity of production to fall, providing another testable implication of the model. ${ }^{9}$

This model has the nice feature that it is consistent with the stylized fact that immigration has little impact on relative wages in local labor markets, and has an additional testable implication that immigration should reduce use of skill-complementary capital, and possibly reduce capital intensity generally. It has the drawback that by simply relabeling the modern and traditional "methods" as modern and traditional "goods" (in a small, open economy) one obtains the same implications; that is, an apparent shift in the method of production might really be a shift in the mix of goods (say, from "low tech" metal fittings to "high tech" machine tools). However, one can distinguish the "methods" from the "goods" interpretation of the model by looking at how the technology used to produce the same goods varies with relative labor supply. For a given good, the "methods" interpretation says technology depends on relative labor supply, while the "goods" interpretation assumes technology is invariant to relative labor supply.

\section{Data}

Surveys of Manufacturing Technology

The technology data used in this project come from the 1988 and 1993 Surveys of Manufacturing Technology (SMT). Each polled a stratified random sample (described below) of around 10,000 manufacturing establishments with at least 20 employees in SIC industries 34-38 on the use of, plans for use of, reasons for use of (or for not using) 17 categories of advanced

\footnotetext{
${ }^{9}$ Beaudry and Green modeled the modern method as less capital intensive (more capital efficient), which is probably not accurate for the technologies being examined in this paper.
} 
manufacturing technologies. ${ }^{10}$ The industries covered by the SMT - fabricated metal products, industrial machinery and equipment, electronic and other equipment, transportation equipment, instruments and related products - make up a large part of the manufacturing sector (43 percent of value added and employment in 1987, according to U.S. Bureau of the Census (1989)).

The SMT technologies (described in Table 1) include processes used both in production and non-production activities, but most of the technologies are for use on the shop floor. Many also appear to replace raw labor, such as automated inspection (alternatively handled by semiskilled "production inspectors"), automated materials handling, and robots. This intuitive assessment of the role of these technologies fits with research showing a positive association between the use of these technologies and the skills of workers at the plant (Doms, Dunne, and Troske (1997)) and by field work evaluating the impact of these technologies (Bartel et al. (2003)). It is also supported by research showing a negative association between computer use and use of labor in repetitive tasks (Autor, Levy, Murnane (2003)).

The SMT surveys also recorded other establishment characteristics, such as plant size, plant age, ownership, production type, military contractor status. These are listed in Table 2. The responses were in categories. Rather than drop observations that did not respond to one of these plant characteristics questions, I treated non-response as a separate category of "response" to each question.

The strata used to create each of the SMT samples consisted of three-digit SIC industry by "class size" cells. There were three class sizes, defined by employment: 20 to 99, 100 to 499, more than 500 employees. (Plants with fewer than 20 employees were not in the survey.) Within each strata, a simple random sample was taken, and a weight was recorded equal to one

\footnotetext{
${ }^{10}$ There was also a 1991 survey, not used in this analysis, which polled firms on the intensity of their use of these technologies in broad categories.
} 
over the sampling rate for that strata. (The average sampling rate was about one-fourth.) Though the SMT was in theory a random sample, it was also a small sample. To ensure that the present analysis would be geographically representative, I constructed new sample weights to properly reflect the geographic distribution of plants in the SMT-universe. I merged each plant in the SMT to the prior-year (1987 and 1992) Census of Manufactures. I then constructed new strata - two-digit SIC industry by class size by metropolitan area. The equivalent to the original SMT weights would be to construct, in each of my new strata, a weight equal to the number of plants in the Census of Manufactures universe divided by the number of plants in the SMT sample. However, this is not what I did. For the purpose of studying the impact on the labor force, I wanted weights that were representative of employment, not plants. So instead, I created a weight equal to strata employment in the Census of Manufactures divided by the number of plants in the SMT. ${ }^{11}$

\section{Empirical Approach}

The initial analysis will consist of cross-sectional regressions of technology use on the relative supply of less-skilled labor in the local work force, regressions of the form:

(4) $T_{j c n}=\alpha_{j}+\theta L S_{c}+\beta^{\prime} X_{j c n}+\varepsilon_{j c n}$

where $\mathrm{T}_{\mathrm{jcn}}$ represents the use of technology at plant $n$ in industry $j$ in city $c$; $\alpha_{\mathrm{j}}$ represents a vector of industry dummies; and $\mathrm{LS}_{\mathrm{c}}$ represents the relative supply of less-skilled labor in city-c. $\mathrm{X}_{\mathrm{jcn}}$ is a vector of plant characteristics. The slope coefficient, $\theta$, measures the impact of less-skilled

\footnotetext{
${ }^{11}$ Merging the SMTs to the prior-year Census of Manufactures had another purpose: it allowed me to merge in information about the plant not available in the SMT, such as employment (which is available only in categories in the SMT).
} 
supply on the use of technology. If the theoretical model presented above is correct, then $\theta$ will be negative in sign; under the null that technology is the same in all locations it is zero.

The most important control variables in this regression are the industry dummies, $\alpha_{j}$. Industries vary in their use of technology and skill mix: electrical machinery, for example, uses both more technology and more skilled labor than the average SMT-covered industry. Also, open-economy models predict differences in worker mix across markets are absorbed by differences in industry mix. An immigration-induced increase in the share of workers who were unskilled, for example, according to trade theory raises the share of the economy's output produced in unskilled-intensive sectors, which could show up as a lesser use of technology. Including industry dummies is equivalent to asking how much local skill ratios shift the method by which the same industries produce.

Plant size, measured by a continuous employment variable from the prior-year Census of Manufactures (1987 or 1992), will also be controlled for in some regressions. Dunne (1994) showed that the relationship between the use of technology and plant size was strong, while the relationship with another factor one might suspect was important, plant age, was weak. In the current context, it is nevertheless not entirely clear that a plant's size should be controlled for. After all, a plant's size may be endogenous, a channel through which local workforce skills affect the use of technology. Therefore, the regression without size controls is also of interest.

The Surveys of Manufacturing Technology also contain several other plant characteristics variables (described in Table 2) which will be controlled for in some regression specifications. One characteristic of interest is product price. Schott (2004) showed that even though there is little international specialization across four-digit industries, countries with a low relative supply of capital or skilled labor tend to specialize in lower quality products within four-digit industries. 
Schott used unit values to measure product quality in his analysis. To capture this possibility, I will include specifications that interact product price categories, indexed by $p$, with industry:

(4') $T_{j c p n}=\alpha_{j p}+\theta L S_{c}+\varepsilon_{j c p n}$

where $\alpha_{\mathrm{jp}}$ represents a vector of industry x product price dummies. Though there are only six price categories in the data, they allow further, albeit crude, disaggregation of the data to test whether the use of technology differs across plants producing similar quality products.

\section{Measuring Skill Mix}

The primary measure of less-skilled relative labor supply used in this paper will be high school dropouts per high school "equivalent." The number of high school equivalents, defined here as the number of workers who are high school graduates plus one-half the number of workers with some college (one to three years college) education, is a commonly used skill aggregate in research on skill biased technological change (for example, Autor, Levy, and Murnane (2003), Katz and Murphy (1992)). ${ }^{12}$ Examining this skill margin - the very low educated relative to those with high school and vocational training - has two motivations. First, it is the margin on which foreign-immigration to U.S. labor markets has the strongest influence, and a major goal of this paper is to understand how immigrants are absorbed into U.S. labor markets. Second, it is a relevant skill margin to affect the use of the mostly production automation related technologies covered by the SMT. Hunt and Hunt's (1983) survey of the

\footnotetext{
${ }^{12}$ In this formulation, those with some college education are thought of as supplying labor inputs "equivalent to" half a high school educated worker and half a four-year college graduate worker. The qualitative results of this paper do not depend on the weight given to some college workers.
} 
potential impact of robotics, for example, talks about the loss of less-skilled jobs in favor of mostly vocationally trained workers and some engineers. Field work examining the impact of these technologies on job skill requirements also supports this view. ${ }^{13}$ This margin also seems appropriate in light of the occupations of dropouts in SMT-covered industries, shown in Table 3 (computed using 1990 Census of Population microdata). Table 3 shows dropouts are highly concentrated in labor-intensive production occupations - assemblers, welders, and inspectors which the automated technologies covered by the SMT might be reasonably argued to replace. Half of dropout workers' hours are concentrated in ten occupations. Immigrant dropouts also work in these same jobs, though they are more concentrated in assembly occupations. In contrast, only 43 percent of high school educated workers' hours and 26 percent of some college educated workers' hours (and 7 percent of college-graduate workers' hours) are in these same jobs - more educated workers have a greater presence in supervisory, managerial, and nonproduction tasks. ${ }^{14}$ Also, in a given occupation, high school and some college educated workers are more skilled - their average wages are higher - and they are likely better equipped to operate newer machines.

I will also examine the impact of other relative skill supply measures on the use of these technologies. In light of the association between the use of these technologies and college share at the plants in the SMT (Doms et al. (1997)), as well as Hunt and Hunt's (1983) prediction that robotics would raise demand for engineers, one might be tempted to look also at the influence of college-educated relative supply. It is worth remembering, however, that college graduates have little presence in production occupations and instead tend to work in high-skill white-collar jobs

\footnotetext{
${ }^{13}$ Bartel et al. (2003) attempt to learn about the impact of new technologies on the skill requirements of production jobs through site visits to several plants in a variety of the same industries covered by the SMT. They find that new technologies increasingly require "soft" skills - communication and problem-solving skills - in addition to math, literacy, and to some extent computer skills. They argue these are skills which can be acquired in high school. ${ }^{14}$ Similar patterns also emerge in looking at a longer list of occupations - say, the top 20.
} 
in management, engineering, computer programming, and sales and marketing. ${ }^{15}$ Nevertheless, the influence of college relative supply will also be examined.

\section{Identification}

Some argue that the use of new technologies, including the ones covered by the SMT, raise relative demand for skilled labor. Dunne and Schmitz (1995), for example, show plantlevel average wages rise with the use of SMT-technologies. Doms et al. (1997) find this, too, but, in contrast, find little evidence that changes over time in the use of SMT technologies were associated with faster growing employment share of skilled workers. Instead, Doms et al. find that plants that adopted more technology had more skilled workers prior to adoption. Nevertheless, if it is true that technology raises skill demand, one might be concerned about interpreting $\theta$ from (4) as the causal impact of skill supply on technology use. Less-skilled workers might seek out "low-tech" markets where the relative demand for less-skilled labor is higher, generating a spurious correlation between technology use and local skill ratios.

To address this concern, I instrument for $\mathrm{LS}_{\mathrm{c}}$. The main instrument $\mathrm{I}$ use can be described as the share of dropouts among "predicted" recent immigrants. The instrument takes advantage of the strong tendency of new immigrants from different parts of the world to settle into U.S. labor markets where immigrants from the same part of the world are already settled (as Bartel (1989) observed) by assigning recent migrants to their historical "enclaves." $" 16$ Validity of

\footnotetext{
15 The top ten occupations, by hours worked in 1990, of college graduates in SMT industries are: managers and administrators (18.9\%), electrical engineers (9.0\%), aerospace engineers $(5.7 \%)$, sales representatives $(4.8 \%)$, mechanical engineers (4.4\%), computer systems analysts (4.4\%), accountants and auditors (4.1\%), marketing, advertising and PR managers (3.8\%), computer programmers (3.5\%), and production supervisors (3.3\%).

${ }^{16}$ Bartel grouped immigrants into three broad world regions: "Asians," "Hispanics," and "Europeans."
} 
this instrument is argued to come from the fact that it captures patterns of migration driven by family and cultural concerns rather than by labor demand. ${ }^{17}$

The instrument assigns newly arriving immigrants to the cities where their countrymen were settled in 1970. The year 1970 is a low point in U.S. history for the presence of foreigners in the U.S. population, and largely precedes the modern wave of less-skilled immigration. Given the lag length, it is expected that immigration predicted on this basis is at most weakly related to local labor demand conditions. Indirect evidence in support of this assertion will be shown below. The main instrument, which is similar to one used in Card (2001), can be written as:

$$
D O_{c t}^{\perp}=\sum_{g} \frac{I M M_{g c, 1970}}{I M M_{g, 1970}} I M M D O_{g t}^{t-5} / \hat{M}_{g t}^{t-5}
$$

Where $\hat{M}_{g t}^{t-5} \equiv \sum_{g} \frac{I M M_{g c, 1970}}{I M M_{g, 1970}} I M M_{g t}^{t-5} . I M M$ and $I M M D O$ represent counts of immigrants and counts of immigrant dropouts, respectively, and $g$ indexes region of origin, and $t$ indexes year. $I M M_{g t}^{t-5}$ represents the count of all immigrants from $g$ who arrived in the U.S. in the past five years (between years $t$ and $t-5$ ), while $I M M D O_{g t}^{t-5}$ represents the immigrants from $g$ who arrived in the U.S. in the past five years and who are high school dropouts; both counts are limited to those in the labor force and aged 16-65. Meanwhile, $\frac{I M M_{g c, 1970}}{I M M_{g, 1970}}$ represents the share of all 16 to 75-year-old immigrants from $g$ - regardless of labor force status or skill - living in city $c$ in

\footnotetext{
${ }^{17}$ Instruments of this nature are often referred to as capturing the "supply-push" part of immigration. George Johnson pointed out in discussion of a related paper that this supply-push term misstates where the variation is coming from - the instrument does not actually make use of conditions in the sending country to predict migrant flows. The instrument implicitly assumes that variation in the national volume of immigrant inflows is driven mainly by variation in conditions in the sending countries, rather than in the destination U.S. markets.
} 
$1970 .^{18}$ Thus, $\frac{I M M_{g c, 1970}}{I M M_{g, 1970}} I M M D O_{g t}^{t-5}$ apportions recent high-school dropout immigrants from $\mathrm{g}$ to the cities where all immigrants from that region were living in 1970; it predicts number of dropouts from country g who recently settled in city c. Summing across regions produces the numerator of (5), total five-year immigration of dropouts to c predicted on the basis of historical immigrant settlement patterns. The denominator of (5), $\hat{M}_{g t}^{t-5}$, apportions all recent immigrants in the same way. Thus $D O_{c t}^{\perp}$ is the fraction of city c's recent "predicted" immigrants who are dropouts.

Table 4 lists the 16 world regions used to construct the instrument, in other words the "g" index in equation (5). It also shows the share of recent immigrants from each region in 1988 and 1993 - the years of the SMT surveys - and the share of recent immigrants who were dropouts in those years, computed using 1990 and 2000 public-use microdata. ${ }^{19}$ The instrument apportions these recent immigrants from each part of the world according to the metropolitan area locations of immigrants from the same part of the world in $1970 .{ }^{20}$ Mexicans, three-quarters of whom are dropouts, are by far the largest group of recent immigrants in both 1988 and 1993. The cities where Mexicans lived in 1970 (the top five were Los Angeles, 32 percent; Chicago, 7 percent; Houston, 4 percent; El Paso, 4 percent; and Anaheim, 4 percent) therefore have a large predicted

\footnotetext{
${ }^{18}$ It might strengthen the first stage to include only workers in the computations of the 1970 shares, but the locations of workers is more likely to be endogenous.

19 For 1988, "recent" immigrants are in fact defined as those who report having arrived 1980-86. (This is the closest approximation to five years prior to 1988 that can obtained using the 1990 Census of Population). For 1993, recent immigrants are defined as those who arrived 1988-93, measured using the 2000 Census of Population. Only working age migrants with at least one year of potential work experience and in the labor force are included in the counts. The population weights in each Census were used to compute the counts.

${ }^{20}$ The locations of immigrants in 1970 are measured using the 1970 Census of Population. Metropolitan areas in the 1970 Census were constructed using county groups, with a county group included in a metropolitan area's definition if a majority of its population resided inside the 1990 boundaries of the metropolitan area. 1970 County population estimates were obtained from U.S. Dept. of Commerce, Bureau of the Census (1984). The 1990 boundaries of the metropolitan areas appear at www.census.gov/population/www/estimates/pastmetro.html. In contrast with the recent immigrant counts, the 1970 locations are computed using all immigrants age 16-75, regardless of labor force status.
} 
dropout share. In contrast, eastern European or central Asian enclaves help predict a low dropout share.

The instrument does a remarkable job of predicting differences in the dropouts/high school equivalents across markets. The first and fourth columns of Table 5 show the relationship between the instrument and dropouts per high school equivalent in 1998 or 1993, measured using Current Population Survey merged outgoing rotation group files (MORGs). ${ }^{21}$ F-stats exceed 60. This strong relationship reveals both the influence that immigration has on local skill supply and the strength of immigrant enclaves in attracting continued migration from the same part of the world, even 20 years later.

The surge in Mexican immigration is an important driver, but it alone does not drive the first-stage relationship. Columns (2) and (5) of Table 5 show that the 1970 Mexican share enters significantly and separately into the first-stage regressions from the main instrument. Finally, supporting the validity of the instrument, controls for employment growth during the period in which the immigrant flows are measured (roughly the five years prior), added in columns (3) and (6), do not significantly affect the first stage. ${ }^{22}$

An advantage of this instrument is that similarly constructed instruments have been used in other research to demonstrate that local skill ratios have little impact on relative wages (Card (2001)) but nevertheless have a large impact on skill ratios in narrow industries (Lewis (2004b)).

\footnotetext{
211988 uses the average of the 1987-1989 MORGs, and 1993 uses the average of the 1992-1994 MORGs. Only those of working age (age 16-65) with at least one year of potential work experience who reported being in the labor force were included in the calculation. CPS final person weights were used in the computations.

${ }^{22}$ Employment is total private non-farm employment and comes from County Business Patterns county summary files. For the 1988 regression, employment growth is measured during 1980-86, the same years in which the immigrant flows are measured. (This has a correlation of 0.7 with 1983-88 employment growth.) Employment growth is measured 1988-93 for 1993. Controls for the wages and employment rates of high school dropouts and graduates are also insignificant and have little effect on the first stage. The 2SLS regressions below use first-stage specifications in columns (2) and (5), though results are robust to using the other specifications. Interestingly, for example, employment growth enters significantly in the reduced form - faster growing places adopt more technology - but the influence of employment growth is orthogonal to that of skill share.
} 
Using the same source of local labor mix variation to evaluate the impact on the use of technology allows the se different results to be linked in a common model.

\section{Other Empirical Issues}

In most of the regressions below, the dependent variable will be a simple count of the number of the 17 technologies in use by the plant. ${ }^{23}$ Although summarizing how "high tech" a plant is in this way potentially masks some interesting variation, this simple count turns out to capture nearly 40 percent of the variation in the individual technologies; factor analysis reveals it to be the principle component. ${ }^{24}$ A number of studies using these data (including Doms et al. (1997)) have summarized technology use in this way. In any case, more disaggregate analysis does not find significant variation in the impact on different technologies. (See Appendix Table A2.) Probably a bigger issue is that it would be desirable to know not just how much the local skill supply affects whether a technology is used, but also how much of it is used. This type of information is available for a limited number of the technologies in the 1993 survey, and will be used in some regressions. In addition, I will evaluate whether the less-skilled labor supply influences a continuous measure of the capital intensity of plants.

In order to obtain the correct standard errors, the regressions were run in two steps: first, the number of technologies was regressed on plant characteristics and city dummies; second, the estimated city dummies - adjusted city level averages - were regressed on the city's dropout share. Regressions were weighted to be representative of employment; correctly interpreted,

\footnotetext{
${ }^{23}$ I assume, as the Census Bureau did throughout most of the reports they published on the results of the SMT $(1989,1994)$, that non-response to any technology use question indicates that the plant is not using that technology.

${ }^{24}$ Beede and Yang (1998) illustrate the potential pitfall of this summary measure: they find that the effect on productivity, employment, and earnings vary by technology, and sometimes even differing in sign. I also find some heterogeneity, but, in contrast, I cannot reject that the impact of dropouts on the use of these technologies is uniformly negative. Given this, the effect on the number of technologies concisely sums up the total effect.
} 
therefore, they measure the impact of citywide dropout share on the number of technologies at "the average employee's plant," but nevertheless they will frequently be described below as the impact at "the average plant." 25

The regressions were run across 143 cities for which all the necessary data were available. ${ }^{26}$ Table 6 shows the means of the dependent variables used in the regressions. In 1988, the average employee in the SMT-universe in these cities was at a plant using six of these technologies; by 1993 this had risen only slightly, to 6.2 technologies. Most of the technologies actually declined in use between 1988 and 1993; the growth in use is confined to computer-based technologies listed in categories I and V of Table $1 .{ }^{27}$ In both 1988 and 1993 there is also wide variation across plants in the use of technology. More than 10 percent of this variation is accounted for by variation across labor markets, even when holding constant industry mix. ${ }^{28}$

Before turning to the results, it is worth finding out how well metro area-wide dropout shares reflect the supply of labor available to manufacturing plants in SMT industries. Figure 2 plots dropouts per high school equivalent in SMT industries (SIC 34-38) against the dropouts per high school equivalent in the city's labor force overall (for my sample of cities). The relationship does not appear to deviate from the 45 degree line in either 1988 or 1993 . More generally, Lewis (2004b) finds an approximately one-for-one relationship between citywide dropout share and dropout share in narrow industries. Figure 2 also demonstrates the tremendous variation across labor markets in the relative supply of less-skilled labor.

\footnotetext{
${ }^{25}$ The employment weights are described in the data section.

${ }^{26}$ The biggest loss of metropolitan areas comes from the requirement that each area must be observable in the 1970 Census of Population, which is used to construct the instrument. Another restriction is that there be at least one plant in the both the 1993 and 1988 SMT surveys, which knocks out an additional 15 metropolitan areas.

${ }^{27}$ McGuckin et al. (1998) also found the 1988-93 increase in use was confined to these categories of technology.

${ }^{28}$ This figure is the amount by which the $\mathrm{R}^{2}$ increases in going from a plant-level technology regression without city dummies to one with city dummies.
} 


\section{Cross-Sectional Results}

Table 7 presents estimates of (4). Columns (1) and (3) show OLS estimates for 1988 and 1993, respectively. The first row shows OLS estimates with no additional controls. The coefficient -4.67 for 1988 says that when the relative supply of dropouts rises by 10 percentage points - slightly less than one standard deviation - the average plant in the city uses 0.467 fewer technologies. A similar estimate is obtained in the 1993 data. This relationship may partly reflect differences in industry mix across locations: areas with more unskilled labor may have more low-technology types of industries. The second row therefore controls for detailed industry, dividing SMT plants into 161 four-digit industries. This does not weaken the relationship! Even within narrow industries, therefore, the use of these technologies varies strongly with the local skill share. To further control for product quality within industry, the third row interacts four-digit industry with the product-price categories (inspired by Schott (2004)). The influence of local skill supply is robust to controls for this proxy for product in both 1988 and 1993.

One might argue that what is really going on is that the use of technology influences the skill composition of the local workforce: low-skill workers are attracted to markets where, for some reason, the use of these (potentially) labor-replacing technologies is lower. To find out if this is the case, we now turn to instrumental variables estimates, using the instrument $D O_{c t}^{\perp}$ described in equation (5) and 1970 Mexican share. Two-stage least squares estimates are presented in columns (2) and (4). Note that these estimates are larger than the OLS estimates. In other words, if anything dropouts differentially live in markets with higher technology use, biasing OLS estimates toward zero. It may also be that immigration-induced less-skilled labor 
supply has a larger impact on technology use than less-skilled labor supply generally, a point discussed further below.

The last three rows of Table 7 present specifications with other plant-level controls. The fourth row shows a specification which controls also for plant employment, entered as a sixthorder polynomial. ${ }^{29}$ Dunne (1994) showed plant size has a strong influence on the use of these technologies, though in this context, where plant size may be endogenous, it is not necessarily appropriate to use it as a control variable. Nevertheless, conditional on plant size, one continues to find a significant, albeit reduced in magnitude, influence of local dropout shares on technology use. The next row adds the first four plant-level controls listed in Table 2 - plant age, nature of manufacturing process, product price, and product market - entered as dummy variables for each category of response. The coefficient on the skill supply variable remains significant in all four columns. The next row adds military contractor variables (controls 5-7 in Table 2). Military contractors generally use more of these technologies (U.S. Bureau of the Census $(1989,1994)$ ), but regional differences in the presence of military contractors do not drive the relationship between technology and local skill supply.

Other controls are available only in the 1993 SMT. It asked about foreign ownership and how much of a plant's production was exported to foreign countries; prior research has found both are associated with higher plant productivity (Bernard and Jensen(2002)) and technology use (U.S. Bureau of the Census (1994)). These controls have little impact on the estimates. Also available are controls on the nature and difficulty of worker training, and whether research and development occurs at the plant. One might interpret these as proxies for "frictions" which may affect the adoption of new technology and be correlated with skill shares. For example, managers at plants that do their own R\&D may be more aware of new technologies; plants that

\footnotetext{
${ }^{29}$ Terms beyond sixth order were never found to be significant and results are insensitive to their inclusion.
} 
do their own training may be able to adapt more quickly to changing technology; both may be more prevalent in more-skilled locations. The last row of the table, however, shows that these controls have little impact on the estimates.

A more continuous measure of the use of these technologies is available in the 1993 survey. For a limited number of technologies, the 1993 survey asked plants to report the "number of dedicated workstations (or items of equipment)." The technologies covered by this question include computer aided design, engineering, and manufacturing; numerically controlled machines; materials working lasers; pick and place and other robots; programmable controllers; and computers used for control on the factory floor. ${ }^{30}$ These make up more than half of the technologies in use at the average worker's plant in 1993. Using this, I created a measure of technological intensiveness, "high tech machines per employee," equal to, for each plant, the number of machines (summed across these technology categories) divided by plant employment. ${ }^{31}$ Table 6 shows that the average worker's plant in 1993 used roughly one machine per nine employees. Many plants used zero machines per employee. Table 8 shows estimates of (4) with this dependent variable for the same specifications as were used in Table 7. All of the estimates are negative and sizeable, though they are imprecisely estimated. Interestingly, controls for plant size do not reduce the coefficient in this case.

Another dependent variable of interest is the overall capital intensity of the plant. Studies generally find that capital complements skilled labor and substitutes for unskilled labor. (Hamermesh (1993) summarizes some of this evidence.) Thus we may expect less-skilled labor supply to reduce the use of capital intensive methods generally. To find out, Table 9 runs (4) using as the dependent variable the log of the (book) value of machinery per employee,

\footnotetext{
${ }^{30}$ Or, in other words, technologies \#1,2,5,6,7,8,16, and 17 in Table 1.

${ }^{31}$ Almost all of the variation in this aggregate comes from differences in the use of programmable controllers.
} 
constructed from 1987 and 1992 Census of Manufactures data, but using the same sample of plants. $^{32}$ This dependent variable averages about $10(\approx \$ 20,000 /$ employee $)$ at the average employee's plant. (See Table 6.) Table 9 shows that this is indeed strongly negatively associated with the local less-skilled labor supply, a relationship which the available controls do not eliminate. The last row of Table 9 controls for the number of technologies in use (entered as dummies), which reduces the magnitude of the coefficient, though it remains marginally significant. In addition to reducing the use of the particular technologies covered by the SMT, less-skilled labor supply reduces relative use of machinery generally. ${ }^{33}$

\section{Robustness}

These results are robust to other formulations of relative less-skilled labor supply. Appendix table A1 shows the results for using dropouts per labor force, rather than per high school equivalent, as the independent variable. Once one adjusts for the fact that the standard deviation of this variable is between half and three times as large as the independent variable used earlier, estimates are all of a similar order of magnitude.

These results by definition imply that the relative supply of workers with at least a high school education is associated with greater use of these technologies. In light of evidence that use of these technologies is higher at plants with relatively more college-educated workers (Doms et al. (1997)), one might also wish to examine more finely the impact of relative supply of these higher levels of education. To this end I also run regressions of the number of

\footnotetext{
${ }^{32}$ For a handful of plants in each year the book value of machinery is reported to be zero, which I took as a missing value in light of the nonzero employment and value added at the same plants. I assigned these plants the mean value of machinery per employee in the plant's metropolitan area (among plants in my sample with nonzero reported machinery). Dropping these plants has little effect on the results.

${ }^{33}$ It is also possible to do the reverse: control for machinery/employee in regressions where the dependent variable is the number of technologies in use. This also reduces only slightly the estimates in Tables 7 and 8 .
} 
technologies on share of the labor force with only a high school degree $\left(\mathrm{HS}_{\mathrm{c}}\right)$, some college but no four-year degree $\left(\mathrm{SC}_{\mathrm{c}}\right)$, and a four-year college degree $\left(\mathrm{GR}_{\mathrm{c}}\right)$ :

(6) $T_{j c n}=\alpha_{j}+\theta_{2} H S_{c}+\theta_{3} S C_{c}+\theta_{4} G R_{c}+\beta^{\prime} X_{j c n}+\varepsilon_{j c n}$

Again I use the impact of historical immigration patterns to produce arguably exogenous variation in local skill shares. I construct instruments in a manner similar to (5) but instead divide recent inflows of immigrants into these three education groups:

$$
\begin{aligned}
H S_{c t}^{\perp} & =\sum_{g} \frac{I M M_{g c, 1970}}{I M M_{g, 1970}} I M M H S_{g t}^{t-5} / \hat{M}_{g t}^{t-5}, S C_{c t}^{\perp}=\sum_{g} \frac{I M M_{g c, 1970}}{I M M_{g, 1970}} I M M S C_{g t}^{t-5} / \hat{M}_{g t}^{t-5}, \\
G R_{c t}^{\perp} & =\sum_{g} \frac{I M M_{g c, 1970}}{I M M_{g, 1970}} I M M G R_{g t}^{t-5} / \hat{M}_{g t}^{t-5}
\end{aligned}
$$

where $\hat{M}_{g t}^{t-5} \equiv \sum_{g} \frac{I M M_{g c, 1970}}{I M M_{g, 1970}} I M M_{g t}^{t-5}$, and $I M M H S_{g t}^{t-5}, I M M S C_{g t}^{t-5}, I M M G R_{g t}^{t-5}$ represent the volume of recent immigrant arrivals of (labor force participants with) high school, some college, and (at least) four-year college graduate levels of education respectively. These variables predict quite strongly the share of high-school and some college-educated workers in the metropolitan areas in the sample. However, they can only weakly predict the college graduate share of an area's labor force, rendering inference about the effect of four-year college graduate relative supply from these instruments impossible. ${ }^{34}$

\footnotetext{
${ }^{34} \mathrm{~A}$ reason for this weak first stage is that the proportion college educated among immigrants and native-born Americans is very similar: there is no relative college graduate "supply shock" associated with immigration.
} 
To alleviate this problem, I add to this list of instruments a dummy for whether or not the metropolitan area has a land-grant college. Moretti (2004b) used this as an instrument for local college share. Land-grant colleges came into existence after 1862, when Congress passed the Morrill Act, giving states land that allowed them to fund the creation of university-level agricultural schools. As Nervis's (1962) history describes, after these land-grant colleges were founded, they moved away from being strictly agricultural schools, and many developed into large universities (for example, the University of Minnesota, the University of California, and the University of Maryland). These schools dramatically increased access to higher education: as Moretti (2004b) showed, areas with land-grant colleges even today tend to have a significantly higher college-educated share. Given the long lag from the founding of these schools until now, and their original purpose of providing support for agriculture, it is not unreasonable to think that the location of these schools is unrelated to unobserved determinants of the skill composition of demand today. The 22 cities in my sample that have land-grant colleges are quite regionally diverse. $^{35}$

First-stage regressions are shown in Table 10. Each column in the table represents a separate regression for a different education share (in 1988 or 1993). The relative supply of a particular education level in an area in 1988 or 1993 is positively associated with 1970 concentrations of immigrants with a high relative supply of that education level. Diagonal elements in the table are positive, while off-diagonals are generally negative or insignificant. The immigrant instruments, however, have little association with college-educated share. The presence of a land-grant college is associated with a significantly ( 5 percentage point) higher

\footnotetext{
${ }^{35}$ Boston, MA; Columbia, SC; Columbus, OH; Des Moines, IA; Greensboro, NC; Hartford, CT; Knoxville, TN; Lansing, MI; Lexington, KY; Lincoln, NE; Madison, WI; Minneapolis, MN; Nashville, TN; Providence, RI; Raleigh-Durham, NC; Richmond, VA; Riverside, CA; Sacramento, CA; San Francisco, CA; Tuscon, AZ; Washington, DC; Wilmington, DE.
} 
college-educated share in an area and does not predict the high school or some college shares. Nevertheless, the first stage overall remains somewhat weak for college-educated workers.

OLS and IV estimates of (6) are shown in Table 11. OLS estimates in the upper panel and IV estimates in the lower panel of the table, and now each column, not row, represents a specification with different controls. All regressions control for industry effects. The coefficients on some college and high school shares are generally large and of similar magnitude, while the coefficient on college graduate share tends to be small and is frequently not distinguished from zero. As before, controls for price categories within industry provide no systematic evidence that this relationship is driven by within-industry product heterogeneity. Size controls absorb a significant part of the relationship, and other plant-level controls have a lesser impact.

The results of these regressions support the main specification of skill supply I used in this paper, which combined high school and some -ducated workers into high school equivalents. The small impact for college graduates is not unexpected in light of the fact that graduates have little presence in the production activities that these technologies are involved in. It does contrast with the strong association between college graduate share and technology use at the plant level (Doms et al. (1997)), but it is consistent with the predictions of researchers in the early 1980s that robotics would increase only slightly demand for college-educated engineers and the like (Hunt and Hunt (1983)).

I have also examined alternative formulations of the technology-use variable. While there are reasons to believe that the impact of less-skilled labor supply might affect some of the 17 technologies more than others, the data do not support these sorts of predictions. Appendix Table A2 shows estimates of the impact of less-skilled relative labor supply on the five 
subcategories of technology listed in Table 1 in equivalent "per technology" terms. All of the estimates in the table control for industry fixed effects, and for reference, the impact on the average technology's use overall is shown at the top of the table (i.e., it just repeats the relevant estimates from Table 7 but divides by 17). The coefficients are not statistically distinguishable from each other. ${ }^{36}$

\section{Do Changes in Skill Mix Affect Changes in Technology Use?}

Another, perhaps stronger, test of whether local skill mix affects the use of technology is to ask whether, as a market's mix of workers changes, the plants in that market adjust their use of technology. This question could be answered by first differencing the data used to run the regressions in Table 7. However, a nice feature of the SMTs is that some plants were sampled in both years, which allows us to first difference at the plant level using a balanced panel - that is, we examine how the same plants change their use of technology when the local skill supply changes. An advantage of panel regressions is that they implicitly remove any unobserved (fixed) attributes of a plant (or city) which affect its use of technology. By itself, however, this approach could still be biased by plant attributes whose influence is changing over time (say, if there were differential trends in technology adoption across industries). Therefore, it still may be important to control for baseline plant characteristics. A disadvantage is that requiring that plants appear in both datasets reduces the sample size considerably, and may produce a sample which overrepresents large plants (McGuckin et al. (1998)). Sample weights will be adjusted to partially address this representation issue.

\footnotetext{
${ }^{36}$ It is of course possible to disaggregate the data even further - down to the individual technology - which I have also done. Again, one cannot reject that the impact of less-skilled relative labor supply is uniformly negative.
} 
The panel approach also allows controls for baseline technology use. This control has several interpretations. First, it captures the "dynamics" of technological change : adoption of new technologies often follows an "S-shaped" pattern over time (e.g. Griliches (1957)) which can be captured by regressing changes on initial levels. Baseline technology use has another useful interpretation in this case: it can roughly be construed as a lagged change in the use of technology, since adoption of most SMT-technologies occurred not long before 1988. For example, according to a large, nationally representative survey of plants in SMT-industries, in 1983 only 6 percent of manufacturing plants used any type of automated assembly, only 3 percent of plants used any type of robotic machine tools, though at least one-quarter of plants were already using numerically-controlled machines (American Machinist (1983)). Regressions which control for technology use in 1988 therefore roughly ask if local influxes of dropouts affect plants' trend-adjusted technology adoption.

Another available control is plants' initial plans for adding technology in the next five years, asked in the 1988 survey. As is evident in Table 6, plants' plans for adding technology considerably overstated how much they ended up adding - on average plants forecasted an increase of three technologies in 1988 , but the average plant had only 0.2 more technologies in 1993. Nevertheless, plans correlate positively with realized changes in the use of technology: a regression of planned additions on actual has a slope coefficient of roughly $0.25{ }^{37}$ Controlling for plant's plans allows us to find out if increases in the availability of unskilled labor cause firms to deviate from their initial plans for technological upgrading.

\footnotetext{
${ }^{37}$ This coefficient alone is not an accurate test of how well firms forecast future technology-use plans. A better test would be to look at the individual technologies plants said they planned to add. In addition, the dependent variable in the regression is a net change in the number of technologies in use, while the control is only for technologies that firms planned to add: firms were not asked about whether they planned to reduce the use of technology.
} 


\section{Results}

OLS and IV regression results for a panel of 1,474 establishments which could be observed in both the 1988 and 1993 surveys are shown in Table 12. In order to correct for the fact that the dropout share varies only across cities, errors are clustered at the city level. In order to correct for the fact that the panel overrepresents large plants, the weights are adjusted to make the panel dataset representative of 1988 employment in the same two-digit industry by class size by metropolitan area cells used earlier. ${ }^{38}$ (See data section.) Reweighting cannot completely fix the representation issue because many cells are "lost" - they have no observations in the panel sample - typically plants in the smallest class size (20-99 employees). There does not appear to be any industry bias to the loss of sample.

The first row of Table 12 shows OLS and IV estimates with no controls. The IV estimates use the instrument $D O_{c, 1993}^{\perp}$ which was used for the 1993 cross-section above. ${ }^{39}$ Both the OLS and 2SLS estimates are negative and similar to the cross-sectional estimates. Unfortunately, the standard errors are also quite large, a problem of working with such a small sample when you have a noisy dependent variable. The second row adds in 17 dummies for plants' 1988 use of technology, which absorbs one-quarter of the variation in technological change across plants and reduces the standard errors considerably. The plants with more technology in 1988 saw slower growth in technology use 1988-93: there was convergence across plants in technology use. ${ }^{40}$ Adding this control raises the point estimate a bit, indicating that the less-skilled labor supply grew faster in places which, based on initial levels of technology use,

\footnotetext{
${ }^{38}$ Using the cross-sectional weights used earlier produces larger and more imprecisely estimated IV estimates.

39 The first stage regression coefficient is 0.23 , with an F-stat of 25. Share of Mexicans in 1970 does not enter significantly and is not used as an instrument here.

${ }^{40}$ If one runs the linear version, the coefficient on the lagged number of technologies is -0.44 .
} 
one would have expected to have had a relatively large amount of technology adoption-places that had low technology use initially.

The third row of the table adds four-digit industry controls, which reduces the OLS but not the IV estimate. Even with these controls, one might still be concerned that the observed effect derives partly from the impact that changes in dropout share have on changes in industry mix (as simple open economy models predict). As a safeguard against this possibility, estimates in the fourth row (and below) also include controls for four-digit industry in 1993; estimates are not lowered by their inclusion. ${ }^{41}$

The fifth row adds a control for the number of technologies plants reported in 1988 that they planned to add in the next five years. Adding it as a control does not reduce the coefficient on the change in dropout share. Influxes of less-skilled workers caused firms to scale back from their initial plans for adding technology. The subsequent rows of the table add in other baseline controls. It is reassuring that these controls have little impact on the IV estimates (which supports the validity of the instrument).

These estimates do not support concerns that the magnitude of the cross-sectional estimates was overstated because of the endogeneity: the panel estimates, in fact, are roughly double the cross-sectional estimates. This occurred during a time when technology use at the average plant grew by a scant 0.2 technologies. The magnitude of these estimates implies that where immigration actually raised less-skilled relative labor supply, some plants may have not only adopted less technology than they otherwise would have, but actually de-adopted technology. McGuckin et al. (1998) found de-adoption to be not uncommon in these data-Table 6 showed that average use fell for some categories, for example. The results of this paper suggest

\footnotetext{
${ }^{41}$ Another way to hold constant industry mix is to restrict the sample to plants which do not change industries between 1988 and 1993. Estimates for this subsample are larger in magnitude.
} 
that the surge in less-skilled migration to the U.S. during the late 1980s may have been a force behind de-adoption.

\section{Specification Test}

Finally, as a specification check we regress plants' plans to add technology in the next five years on the future change in dropout share. The purpose of this is to test whether the negative relationship between technology use and dropout share found so far is driven by the endogenous differential migration of less-skilled workers to markets where technological change was expected to be slower. Table 13 shows most of the specifications from Table 7 and uses the 1988 cross-section sample and weights, except that the dependent variable is now the number of technologies plants reported in 1988 they would add by 1993. The last row adds controls for the number of technologies in use in 1988, which was found above to be an important determinant of technology additions 1988-1993. OLS estimates are in column (1). All of them are positive, though not statistically significant. IV estimates, which use the same instruments as the 1993 cross-sectional regressions above, are shown in column (2). These are also positive, of similar magnitude, and statistically insignificant. This is a reassuring finding, supporting the idea that the direction of causality does indeed run from skill supply to technology use and not the other way around. If anything, dropouts weakly favor future "high-tech" markets. It is not clear why this would be the case, but it is consistent with a bias toward zero in the OLS estimates. ${ }^{42}$

\footnotetext{
${ }^{42}$ Another feasible specification test is to take advantage of the fact that the IV regressions are overidentified-there are two instruments for one endogenous variable in the cross-section regressions. Hausman overidentification tests do not reject the exogeneity assumption. It is worth remembering, however, that this test conditions on at least one of the instruments being valid.
} 


\section{Discussion}

In all of the analysis presented in this paper, a higher local relative supply of less-skilled labor was associated with lower use of manufacturing automation technologies at otherwise similar plants. This was true in both cross section and in first differences. The effect was larger when using variation in local skills supplies generated by arguably exogenous historical patterns of immigration. There are a number of reasons why IV estimates might be larger than OLS estimates. One is that immigrant less-skilled labor supply may have a greater impact on technology use than overall less-skilled labor supply. Table 3 showed that immigrant dropouts were more likely to be in the assembly tasks which some of these technologies replace. In addition, because new immigrants tend to follow previous waves of immigrants to the same destination, an increase in the presence of less-skilled migrants tends to raise the less-skilled labor supply not only now, but also in the future. Producers may anticipate future flows of lessskilled immigrants by adopting less technology. ${ }^{43}$

The results of this paper suggest that plants use automation as a substitute for less-skilled labor, as one might suspect on a priori grounds. This is similar to what Lewis (2004b) found for on-the-job use of computers and what Nestoriak (2004) found for computer investment. Lewis (2004b) found computer use rose less rapidly where immigration induced faster growth in the local relative supply of less-skilled labor. Nestoriak (2004) found computer investment was higher in counties with a relative employment of skilled labor. Researchers have also argued for some time that computer-based technologies lower relative demand for less-skilled labor (Krueger (1993)). This paper finds the "reverse" - the relative supply of less-skilled labor reduces demand for technology. It is possible for both to be to some extent true: notably, the association between skills and technology across markets is considerably weaker than the plant-

\footnotetext{
${ }^{43}$ In addition, any attenuation of the OLS estimates due to measurement error is eliminated in the IV regressions.
} 
level relationship examined in Doms et al. (1997) (though these authors do not argue that the association implies that technology use raises skill demand). Nevertheless, the results of this and other papers which find evidence of input supply-driven technological change caution against interpreting observed associations between technology use and skills as evidence that technological advances have raised relative demand for skills.

The results also potentially help to explain the why local labor market impact of immigration on native-born wages has be found consistently to be small (Borjas (1994), Friedberg and Hunt (1995)). It may be that the technology employers use - rather than the relative wages they pay - adjusts to local labor mix. The results of this paper are consistent with a Beaudry and Green (2000)-style model of endogenous technology choice, in which areas with a high relative supply of less-skilled labor make greater use of less-skilled intensive production methods. In the version of the model used in this paper, less-skilled relative wages are insensitive to relative supply as a result of the adjustment of technology. This model is therefore a strong candidate to explain how local labor markets adapt to immigration.

The main caveat to these results is that what I interpret as differences in "technology" may also reflect systematic differences in product mix below the level of industry detail observable to me (four-digit SIC). Among other things, the lesser use of technology in low-skill markets is partly mediated through the greater presence of small plants in those markets, which may indicate the production of more specialty or customized products in those markets. Schott (2004) provides indirect cross-country evidence that product quality within narrow industries varies according the local skill and capital supply. In order to clarify the interpretation of my results, I controlled for a crude measure of product quality within industry, and found that this had little effect on the results. While this does not rule out that more detailed data would reveal 
that the results were driven by within industry differences in product quality, it is encouraging for the interpretation I give to the data. In any case, shifts in product mix could also explain the insensitivity of relative wages to immigration (in light of standard open-economy models). ${ }^{44}$

\section{Conclusion}

This paper has explored the impact of local skill supply on the use of automated technologies by manufacturing plants. In the conventional view of recent empirical work on technological adoption, local skill supply has no impact on the use of technology. In contrast, I find that the use of these technologies in both 1988 and 1993 was strongly decreasing in the local relative supply of less-skilled (high-school dropout) labor. The result is robust to controls for detailed (four-digit SIC) industry and other plant characteristics, and if anything, the effect is greater when using arguably exogenous historical patterns of less-skilled immigration as an instrument. Furthermore, when the share of workers who are dropouts in a plant's local labor market rises, the plant reduces growth in the use of automated technology both overall and relative to its initial plans.

The results of this paper are consistent with a model which can explain why repeated studies have turned up little evidence that immigrant shocks to local skill ratios have an impact on relative wages. Recent theoretical models of endogenous technological choice (Beaudry and Green (2000)) remind us of the theoretical possibility that employers may adapt to less-skilled immigration by altering the method of production, leaving relative wages insensitive to supply. The intuition is similar to a standard open economy model. The facts so far fit this model production methods (in narrow industries) are sensitive to local skill mix, while relative wages

\footnotetext{
${ }^{44}$ Another alternative interpretation of the relationship between technology and skills across markets is that skilled labor is better able to implement new technologies (Bartel and Lichtenberg (1987)). However, this explanation seems unhelpful for explaining why changes in technology are associated with changes in local skill supply.
} 
are not, though some of the shift in methods could be due to unobservable shifts in the types of products being produced within narrow industries.

Finally, the results of this paper are consistent with recent cross-country evidence that computer adoption responds to skill mix (Caselli and Coleman (2001)). The response of this and other technologies to input supplies are claimed to be a potential expla nation of the persistence of income differences across countries (Keller (2004)). The finding that even within the U.S. there are major within-industry differences in the use of technology related to local skill shares provides strong support for this view. 


\section{References}

Acemoglu, Daron (1998). "Why Do New Technologies Complement Skills? Directed Technical Change and Wage Inequality." Quarterly Journal of Economics 113(4): November 1998, p. 1055-89.

---- (2002). “Technical Change, Inequality and the Labor Market.” Journal of Economic Literature 40(1): March 2002, p. 7-72.

American Machinist (1983). " $13^{\text {th }}$ American Machinist Inventory." American Machinist 127(11): November 1983, p. 113-144.

Autor, David H., Lawrence F. Katz and Alan B. Krueger (1998). “Computing Inequality: Have Computers Changed the Labor Market?" Quarterly Journal of Economics 113(4): November 1998, p. 1169-1213.

Autor, David H., Frank Levy and Richard J. Murnane (2003). "The Skill Content of Recent Technological Change: An Empirical Exploration." Quarterly Journal of Economics 118 (4): November 2003, p. 1279-1334.

Bartel, Ann (1989). "Where Do the New US Immigrants Live?" Journal of Labor Economics 7(4): October 1989, p 371-91.

Bartel, Ann, Casey Ichniowski, and Kathryn Shaw (2003). “'New Technology” and Its Impact on the Jobs of High School Workers: A Look Deep Inside Three Manufacturing Industries." In Eileen Appelbaum et. al., eds. Low Wage America: How Employers are Reshaping Opportunity in the Workplace. New York: Russell Sage Foundation, 2003, p.155-194.

Bartel, Ann, and Frank Lichtenberg (1987). "The Comparative Advantage of Educated Workers in Implementing New Technology: Some Empirical Evidence." Review of Economics and Statistics 69(1): February 1987, p. 1-11.

Beaudry, Paul, and David A. Green (2000). "What is Driving US and Canadian Wages: Exogenous Technical Change or Endogenous Choice of Technique?" University of British Columbia mimeo, January 2000.

---- (2003). "Wages and Employment in the United States and Germany: What Explains the Differences?" American Economic Review 93(3): June 2003, p. 573-602.

Beede, David N., and Kan H. Young (1998). "Patterns of Advanced Technology Adoption and Manufacturing Performance." Business Economics 33(2): April 1998, p. 43-48.

Bernard, Andrew B., and J. Bradford Jensen (2002). "The Deaths of Manufacturing Plants." National Bureau of Economic Research Working Paper \#9026. Cambridge, MA: NBER, June 2002. 
Borjas, George, J. (1994). "The Economics of Immigration." Journal of Economic Literature 32: December 1994, p. 1667-1717.

Bound, John, and George Johnson (1992). "Changes in the Structure of Wages in the 1980s: An Evaluation of Alternative Explanations." American Economic Review 82 (3): June 1992, p. 371-392.

Bowen, Harry P., Edward E. Leamer, and Leo Sveikauskas (1987). "Multicountry, Multifactor Tests of the Factor Abundance Theory." American Economic Review 77(5): December 1987, p. 791-809.

Card, David (2001). "Immigrant Inflows, Native Outflows, and the Local Labor Market Impacts of Higher Immigration." Journal of Labor Economics 19(1): January 2001, p. 22-64.

Caselli, Francesco, and Wilbur John Coleman II (2001). "Cross-Country Technology Diffusion: The Case of Computers." American Economic Review 91(2): May 2001, p. 328-35.

DiNardo, John, and Jorn-Steffen Pischke (1997). "The Returns to Computer Use Revisited: Have Pencils Changed the Wage Structure, Too?" Quarterly Journal of Economics 112(1): February 1997, p. 291-303.

Doms, Mark, Timothy Dunne, and Kenneth R. Troske (1997). "Workers, Wages and Technology." Quarterly Journal of Technology 62(1): February 1997, p 253-90.

Dunne, Timothy (1994). "Plant Age and Technology Use in US Manufacturing Industries." RAND Journal of Economics 25(3): Autumn 1994, p. 488 - 499.

Dunne, Timothy, Lucia Foster, John Haltiwanger and Kenneth R. Troske (2004). "Wage and Productivity Dispersion in U.S. Manufacturing: The Role of Computer Investment." Journal of Labor Economics 22(2): April 2004, p. 397-430.

Dunne, Timothy, and James Schmitz, Jr. (1995). "Wages, Employment Structure and Employer Size-Wage Premia: Their Relationship to Advanced Technology Usage at U.S. Manufacturing Establishments.” Economica 62: February 1995, p. 89-107.

Friedberg, Rachel M., and Jennifer Hunt (1995). "The Impact of Immigrants on Host Country Wages, Employment and Growth." Journal of Economic Persepctives 9(2): Spring 1995, p. 23-44.

Griliches, Zvi (1957). "Hybrid Corn: An Exploration in the Economics of Technological Change." Econometrica 25(4): October 1957, p. 501-522.

Habakkuk, H.J. (1962). American and British Technology in the Nineteenth Century: The Search for Labor-Saving Inventions. London: Cambridge University Press, 1962.

Hamermesh, Daniel S. (1993). Labor Demand. Princeton, NJ: Princeton University Press, 1993. 
Hanson, Gordon H., and Matthew J. Slaughter (2002). "Labor-Market Adjustments in Open Economies: Evidence from US States.” Journal of International Economics 57(1): June 2002, p. 3-29.

Hunt, H. Allen, and Timothy L. Hunt (1983). Human Resource Implications of Robotics. Kalamazoo, Michigan: W. E. Upjohn Institute for Employment Research, 1983.

Johansen, Leif (1959). "Substitution Versus Fixed Production Coeffcients in the Theory of Economic Growth: A Synthesis." Econometrica 27(2): April 1959, p. 157-175.

Kane, Thomas J., and Douglas O. Staiger (2002). "Volatility in School Test Scores: Implications for Test-Based Accountability Systems" in Diane Ravitch, ed., Brookings Papers on Education Policy, 2002. Washington, D.C.: Brookings Institution, p. 235-283.

Katz, Lawrence, and Kevin Murphy (1992). "Changes in Relative Wages, 1963-1987: Supply and Demand Factors." Quarterly Journal of Economics 112: 1992, p. 291-303.

Keller, Wolfgang (2004). “International Technology Diffusion.” Journal of Economic Perspectives 42(3): September 2004, p. 752-782.

Krueger, Alan (1993). "How Computers Have Changed the Wage Structure: Evidence from Microdata 1984-1989.” Quarterly Journal of Economics 108(1): 1993, p. 33-60.

Krusell, Per, Lee E. Ohanian, Jose-Victor Rios-Rull, and Giovanni L. Violante (2000). "CapitalSkill Complementarity and Inequality: A Macroeconomic Analysis." Econometrica 68 (5): September 2000, p. 1029-1053.

Leamer, Edward E. (1995). The Heckscher-Ohlin Model in Theory and Practice. Princeton Studies in International Finance vol 77. Princeton, NJ: International Finance Section, 1995.

Lewis (2004a). "How Did the Miami Labor Market Absorb the Mariel Immigrants?" Federal Reserve Bank of Philadelphia Working Paper 04-03, January 2004.

Lewis (2004b). "How Do Local Labor Markets in the U.S. Adjust to Immigration?" Federal Reserve Bank of Philadelphia. Mimeo, November 2004.

Luque, Adela, and Javier Miranda (2005). "Technology Use and Worker Outcomes: Direct Evidence from Linked Employee-Employer Data." Washington, D.C.: Center for Economic Studies mimeo, 2005.

McGuckin, Robert H., Mary L. Streitwieser, and Mark Doms (1998). "The Effect of Technology Use on Productivity Growth." Economics of Innovation and New Technology 7(1): 1998, p. 1-26. 
Moretti, Enrico (2004a). "Workers' Education, Spillovers and Productivity: Evidence from Plant-Level Production Functions." American Economic Review 94(3): June 2004, p. 656-90.

--- (2004b). "Estimating the Social Return to Higher Education: Evidence From Longitudinal and Repeated Cross-Sectional Data." Journal of Econometrics 121(1-2): July- August 2004, p. 175-212.

Nervis, Allan (1962). The State Universities and Democracy. Urbana, IL: University of Illinois Press, 1962.

Nestoriak, Nicole (2004). "Labor Market Skill, Firms, and Workers.” Ph.D. diss., University of Maryland.

Schott, Peter K. (2004). "Across-Product versus Within-Product Specialization in International Trade." Quarterly Journal of Economics 119(2): May 2004, p. 647-678.

Solow, Robert M. (1962). "Substitution and Fixed Proportions in the Theory of Capital." Review of Economic Studies 29(3): June 1962.

Stiroh, Kevin J. (2002). "Information Technology and the U.S. Productivity Revival: What Do the Industry Data Say?" American Economic Review 92(5): December 2002, p. 1559 1576.

U.S. Dept. of Commerce, Bureau of the Census (1984). "Intercensal Estimates of the Population of Counties by Age, Sex, and Race [United States]: 1970-1980 [Computer file]." ICPSR version. Washington, DC: U.S. Dept. of Commerce, Bureau of the Census [producer], 1984. Ann Arbor, MI: Inter-university Consortium for Political and Social Research [distributor], 2000.

---- (1989). Manufacturing Technology 1988. SMT(88)-1. Washington, DC: US Government Printing Office, 1989.

---- (1993). Manufacturing Technology: Factors Affecting Adoption 1991. SMT(91)-2. Washington, DC: US Government Printing Office, 1993.

---- (1994). Manufacturing Technology: Prevalence and Plans for Use 1993. SMT(93)-3. Washington, DC: US Government Printing Office, 1994. 


\section{Table 1. Description of Technologies Covered in Surveys of Manufacturing Technology}

\section{Design and Engineering}

1. Computer-Aided Design (CAD) and/or Computer-Aided Engineering - "Use of computers for drawing and designing parts or products and for analysis and testing of designed parts or products."

2. Computer-Aided Design (CAD)/Computer-Aided Manufacturing (CAM) - "Use of CAD output for controlling machines used to manufacture the part or product."

3. Digital Data Representation - "Use of digital representation of CAD output for controlling machines used in procurement activities."

\section{Fabrication and Machining}

4. Flexible Manufacturing Cell (FMC)/Flexible Manufacturing System (FMS). $F M C$ - "Two or more machines with automated material handling capabilities controlled by computers or programmable controllers, capable of single path acceptance of raw material and single path delivery of finished product."

$F M S$ - "Two or more machines with automated material handling capabilities controlled by computers or programmable controllers, capable of multiple path acceptance of raw material and multiple path delivery of finished product. A FMS may also be comprised of two or more FMC linked in series or parallel."

5. $\mathrm{NC/CNC}$ Machine - "A single machine either numerically controlled (NC) or computer numerically controlled (CNC) with or without automated material handling capabilities. NC machines are controlled by numerical commands, punched on paper or plastic mylar tape while CNC machines are controlled electronically through a computer reading in the machine."

6. Materials Working Laser - "Laser technology used for welding, cutting, treating, scribing and marking."

7. Pick and Place Robots - "A simple robot, with one, two, or three degrees of freedom, which transfers items from place to place by means of point-to-point moves. Little or no trajectory control is available."

8. Other Robots - "A reprogrammable, multifunctional manipulator designed to move materials, parts, tools or specialized devices through variable programmed motions for the performance of a variety of tasks."

\section{Automated Materials Handling}

9. Automated Storage and Retrieval Systems (AR/RS) - "Computer controlled equipment providing for the automatic handling and storage of materials, parts, subassemblies, or finished products."

10. Automatic Guided Vehicle Systems (AGVS) - "Vehicles equipped with automatic guidance devices programmed to follow a path that interfaces with work stations for automated or manual loading and unloading of materials, tools, parts or products."

\section{(Continued)}


Table 1. (Continued)

IV. Automated Inspection and Quality Control

Automated Sensor Based Inspection And/Or Testing Equipment - "Includes automated sensor based inspection and/or testing performed on incoming or inprocess materials, or performed on the final product."

11. Performed on Incoming Materials

12. Performed on Final Product

\section{Communications and Control}

13. Technical Data Network - "Use of local area network (LAN) technology to exchange technical data with design and engineering documents."

14. Factory Network - "Use of local area network (LAN) technology to link information between different points on the factory floor."

15. Intercompany Computer Network - "Use of network technology to link subcontractors, suppliers and/or customers with the plant."

16. Programmable Controllers - "A solid state industrial control devise that has programmable memory for storage of instructions, which performs functions equivalent to a relay panel or wired solid state logic control system."

17. Computers Used for Control on the Factory Floor - "Exclude computers imbedded within machines, or computers used solely for data acquisitions or monitoring. Include computers that may be dedicated to control but are capable of being programmed for other functions."

Source: US Bureau of the Census (1989), US Bureau of the Census (1994). 
Table 2. Plant Characteristics Variables in the Surveys of Manufacturing Technology

\section{Available in Both 1988 and 1993}

1. Plant Age. "How Many Years Has this Establishment Manufactured Products at this Location?" (A) Less than 5 years; (B) 5-15 Years; (C) 16-30 Years; (D) Over 30 Years.

2. Nature of Manufacturing. (A) Fabrication/Machining; (B) Assembly; (C) Fabrication/Machining and Assembly; (D) Neither Fabrication/Machining nor Assembly.

3. Product Price. "What is the average market price for MOST products of this plant?" (A) Less than $\$ 5$; (B) $\$ 5-\$ 100$; (C) $\$ 101-\$ 1,000$; (D) $\$ 1,001-\$ 2000$; (E) $\$ 2,001$ to $\$ 10,000$; (F) Over $\$ 10,000$.

4. Market. "What is the market for MOST of the products of this plant?" (A) Consumer (personal use by household); (B) Commercial (e.g., offices, hospitals, services, etc.) (C) Industrial (manufacturing, mining, construction, and utilities); (D) Transportation; (E) Government; (F) Other in 1993 and (F) Can't Specify in 1988.

5. Any Military. "Are any of the products produced in this plant manufactured to military specifications?" (A) Yes; (B) No; (C) Don't know.

6. Percent Shipped to Federal Defense Agencies. (A) 1-25\%; (B) 26-75\%; (C) Over 75\%; (D) None; (E) Don't Know.

7. Percent Shipped to Prime Contractors of Federal Defense Agencies. (A) 1-25\%; (B) 2675\%; (C) Over 75\%; (D) None; (E) Don’t Know.

\section{Available in 1993 Only}

8. Exporter. "What percent of this plant's total value of shipments are exported for direct sale? Include shipments to foreign subsidiaries." (A) None; (B) Less than 10\%; (C) 10 to 19\%; (D) 20 to $49 \%$; (E) $50 \%$ or more

9. R\&D. "Where is most of the research and development work for this plant done?" (A) Outside the firm; (B) In this plant; (C) Elsewhere in the firm; (D) No research and development done.

10. Training - location. "Where is most of the formal training for staff of this plant conducted?" (A) In this plant; (B) Elsewhere in the firm; (C) Outside the firm; (D) No formal training for staff - skip to 13.

11. Training - personnel. "Who conducts most of the formal training for staff of this plant?" (A) Staff from this plant; (B) Staff from elsewhere in the firm; (C) Trainers from outside the firm.

12. Hiring Difficulty. "How difficult has it been to hire skilled personnel to work with the technologies used in this plant?" (A) Not difficult; (B) Some problems; (C) Very difficult.

13. Foreign Ownership. "Does a foreign entity (company, individual, government, etc.) own, directly or indirectly, 10 percent or more of the voting stock or other equity rights in this plant?" (A) Yes; (B) No; (C) Don't know.

Source: US Bureau of the Census (1989), US Bureau of the Census (1994). 


\section{Table 3. Top Occupations of High School Dropouts by Percent of Hours Worked}

SMT industries, 1990

All Dropouts \begin{tabular}{c} 
Immigrant \\
Dropouts \\
\hline
\end{tabular}

Assemblers

13.8

15.0

Electrical Equip. Assemblers

5.5

9.3

Welders and Cutters

5.3

4.6

Machine Operators, Not Spec.

5.1

7.4

Supervisors, Production Occs

5.0

4.3

Machinists

5.0

5.1

Miscellaneous Machine Ops

3.4

5.3

Production Inspectors

3.1

2.9

Laborers

2.6

2.7

Janitors and Cleaners

2.1

1.8

Top 10 Occupations

50.9

58.5

Data Source: 1990 Census of Population public-use microdata. Among those working in industries covered by the SMT, figures show the percent of hours worked by members of the group identified (e.g. immigrant high school dropouts) employed in the given occupation. 
Table 4. Origin Mix and Skills of Recent Immigrants in 1988 and 1993

\begin{tabular}{|c|c|c|c|c|}
\hline \multirow[t]{2}{*}{ Origin Region } & \multicolumn{2}{|c|}{ Shr. of Recent Imms } & \multicolumn{2}{|c|}{$\begin{array}{l}\text { Rec. Imm Shr. } \\
\text { Dropout }\end{array}$} \\
\hline & 1988 & 1993 & 1988 & 1993 \\
\hline & $(1)$ & $(2)$ & (3) & $(4)$ \\
\hline Mexico & 0.257 & 0.298 & 0.756 & 0.670 \\
\hline Caribbean & 0.082 & 0.077 & 0.423 & 0.334 \\
\hline Central America & 0.101 & 0.086 & 0.602 & 0.591 \\
\hline China, HK, Singapore & 0.060 & 0.062 & 0.239 & 0.188 \\
\hline South America & 0.072 & 0.063 & 0.283 & 0.226 \\
\hline SE Asia/Pac. Island & 0.075 & 0.066 & 0.373 & 0.351 \\
\hline Korea \& Japan & 0.044 & 0.031 & 0.140 & 0.086 \\
\hline Philippines & 0.063 & 0.052 & 0.114 & 0.094 \\
\hline Canada, Aust/NZ/UK etc. & 0.038 & 0.037 & 0.103 & 0.064 \\
\hline India, Pakistan, Centr Asia & 0.048 & 0.055 & 0.126 & 0.103 \\
\hline Russia \& Eastern Europe & 0.034 & 0.075 & 0.177 & 0.100 \\
\hline Southwestern Europe & 0.016 & 0.011 & 0.439 & 0.256 \\
\hline Northern Europe \& Israel & 0.021 & 0.024 & 0.086 & 0.086 \\
\hline Turkey, N. Africa, Mid. East & 0.032 & 0.025 & 0.119 & 0.129 \\
\hline Other Africa & 0.026 & 0.029 & 0.097 & 0.120 \\
\hline Cuba & 0.030 & 0.011 & 0.535 & 0.381 \\
\hline
\end{tabular}

Data Source: 1990 and 2000 public-use Census of Population. Columns (1) and (3) show statistics on the $3,118,709$ immigrants who reported arriving in the U.S. between 1980-86 according to the 1990 Census while column (2) and (4) show the same statistics on the

$3,631,347$ immigrants who reported arriving between 1988 and 1993, according to the 2000

Census. Only working-age immigrants (age 16-65 and old enough to have completed reported years of school) not living in group quarters, with at least one year of work experience, and who report being in the labor force are included in the calculations for columns (1)-(4). 
Table 5. First Stage Regressions, 1988 and 1993

\begin{tabular}{|c|c|c|c|c|c|c|}
\hline \multirow[b]{2}{*}{ Variable } & \multicolumn{3}{|c|}{1988} & \multicolumn{3}{|c|}{1993} \\
\hline & (1) & $(2)$ & (3) & (4) & $(5)$ & (6) \\
\hline $\begin{array}{l}\text { Dropout Share of } \\
\text { "Predicted" Imms }\end{array}$ & $\begin{array}{c}0.50 \\
(0.06)\end{array}$ & $\begin{array}{c}0.23 \\
(0.06)\end{array}$ & $\begin{array}{c}0.22 \\
(0.06)\end{array}$ & $\begin{array}{c}0.66 \\
(0.06)\end{array}$ & $\begin{array}{c}0.40 \\
(0.06)\end{array}$ & $\begin{array}{c}0.41 \\
(0.06)\end{array}$ \\
\hline $\begin{array}{l}1970 \text { Share of } \\
\text { Mexican Imms }\end{array}$ & & $\begin{array}{l}0.76 \\
(0.08)\end{array}$ & $\begin{array}{c}0.77 \\
(0.09)\end{array}$ & & $\begin{array}{c}0.84 \\
(0.10)\end{array}$ & $\begin{array}{c}0.84 \\
(0.11)\end{array}$ \\
\hline $\begin{array}{l}\text { "5-year" prior em- } \\
\text { ployment growth }\end{array}$ & & & $\begin{array}{c}0.02 \\
(0.05)\end{array}$ & & & $\begin{array}{l}-0.01 \\
(0.09)\end{array}$ \\
\hline $\begin{array}{l}\mathrm{R}^{2} \\
\text { F-Stat, Instruments }\end{array}$ & $\begin{array}{l}0.31 \\
62.1\end{array}$ & $\begin{array}{l}0.56 \\
89.3\end{array}$ & $\begin{array}{l}0.56 \\
88.7\end{array}$ & $\begin{array}{c}0.42 \\
103.0\end{array}$ & $\begin{array}{c}0.62 \\
112.8\end{array}$ & $\begin{array}{c}0.62 \\
108.6\end{array}$ \\
\hline
\end{tabular}




\section{Table 6. Descriptive Statistics for Dependent Variables}

\begin{tabular}{|c|c|c|c|c|c|}
\hline & \multicolumn{2}{|c|}{ Mean } & \multicolumn{2}{|c|}{ Standard Deviation } & \multirow[t]{2}{*}{ Range } \\
\hline & 1988 & 1993 & 1988 & 1993 & \\
\hline Number of Technologies in Use & 6.01 & 6.20 & 4.68 & 4.45 & $0-17$ \\
\hline I. Computer aided design & 1.25 & 1.44 & 1.06 & 1.01 & $0-3$ \\
\hline II. Fabrication \& machining & 1.57 & 1.48 & 1.52 & 1.38 & $0-5$ \\
\hline III. Automated material handling & 0.30 & 0.27 & 0.61 & 0.56 & $0-2$ \\
\hline IV. Automated Inspection & 0.61 & 0.59 & 0.84 & 0.82 & $0-2$ \\
\hline V. Communication and control & 2.27 & 2.42 & 1.81 & 1.84 & $0-5$ \\
\hline Workstations/Employee & & 0.11 & & 0.28 & \\
\hline Log machinery/employee & 10.0 & 10.3 & 0.89 & 0.95 & \\
\hline No. of techs plan to add in 5yrs & 2.85 & & 2.90 & & $0-17$ \\
\hline
\end{tabular}

Variables in first six rows represent counts of the number of technologies in use in a given category. See Table 1 for description of technologies. Descriptive statistics are computed for the subsample of plants used in the analysis, which includes 6,571 plants in 1988 and 4,757 plants in 1993. See text for details. 
Table 7. The Impact of Citywide Dropout/High School Equivalents on \# of Technologies in Use

\begin{tabular}{|c|c|c|c|c|}
\hline \multirow{3}{*}{ Controls } & \multicolumn{2}{|c|}{$\begin{array}{c}1988 \\
N=6,571\end{array}$} & \multicolumn{2}{|c|}{$\begin{array}{c}1993 \\
N=4,757\end{array}$} \\
\hline & OLS & IV & OLS & IV \\
\hline & (1) & (2) & (3) & (4) \\
\hline No Controls & $\begin{array}{l}-4.67 \\
(1.29)\end{array}$ & $\begin{array}{l}-4.96 \\
(1.69)\end{array}$ & $\begin{array}{l}-3.83 \\
(1.01)\end{array}$ & $\begin{array}{l}-3.22 \\
(1.27)\end{array}$ \\
\hline 4-digit-industry & $\begin{array}{l}-4.17 \\
(1.17)\end{array}$ & $\begin{array}{l}-6.51 \\
(1.55)\end{array}$ & $\begin{array}{l}-4.36 \\
(0.90)\end{array}$ & $\begin{array}{l}-5.27 \\
(1.13)\end{array}$ \\
\hline $\begin{array}{l}\text { 4-digit-industry } \\
\text { x product price* }\end{array}$ & $\begin{array}{l}-4.42 \\
(1.14)\end{array}$ & $\begin{array}{l}-6.22 \\
(1.51)\end{array}$ & $\begin{array}{l}-3.59 \\
(0.75)\end{array}$ & $\begin{array}{l}-4.32 \\
(0.93)\end{array}$ \\
\hline $\begin{array}{l}\text { 4-digit industry, } \\
\text { plant sz polynm** }\end{array}$ & $\begin{array}{l}-2.06 \\
(0.82)\end{array}$ & $\begin{array}{l}-3.10 \\
(1.07)\end{array}$ & $\begin{array}{l}-2.80 \\
(0.71)\end{array}$ & $\begin{array}{l}-3.55 \\
(0.89)\end{array}$ \\
\hline $\begin{array}{l}\text { Previous }+ \text { other }^{\star \star \star} \\
\text { controls. }\end{array}$ & $\begin{array}{l}-1.93 \\
(0.67)\end{array}$ & $\begin{array}{l}-2.60 \\
(0.87)\end{array}$ & $\begin{array}{l}-1.34 \\
(0.52)\end{array}$ & $\begin{array}{l}-2.12 \\
(0.65)\end{array}$ \\
\hline $\begin{array}{l}\text { Previous + Military } \\
\text { Contractor Controls }\end{array}$ & $\begin{array}{l}-1.95 \\
(0.68)\end{array}$ & $\begin{array}{l}-2.82 \\
(0.89)\end{array}$ & $\begin{array}{l}-1.36 \\
(0.52)\end{array}$ & $\begin{array}{l}-2.18 \\
(0.65)\end{array}$ \\
\hline $\begin{array}{l}\text { Previous + Exporter, } \\
\text { Foreign Ownership }\end{array}$ & & & $\begin{array}{l}-1.48 \\
(0.52)\end{array}$ & $\begin{array}{l}-2.30 \\
(0.65)\end{array}$ \\
\hline $\begin{array}{l}\text { Previous + Training } \\
\text { and R\&D }\end{array}$ & & & $\begin{array}{l}-1.28 \\
(0.49)\end{array}$ & $\begin{array}{l}-2.01 \\
(0.62)\end{array}$ \\
\hline
\end{tabular}

* Seven categories of "prices charged for most products" (including "no response" category) fully interacted $\mathrm{w} /$ four digit industry. See Table 2. ${ }^{* *} 6$ th order polynomial in plant employment. ${ }^{* * *}$ Controls 1-4 in Table 2. Columns (2) uses as the instrumental variable high school dropout share among "predicted" (from 1970 locations of immigrants from 16 world regions) immigrants who arrived 1980-86 and 1970 Mexican share. Columns (4) uses as the instrumental variable high school dropout share among "predicted" immigrants who arrived 1988-93 and 1970 Mexican share. Standard errors robust to clustering within metropolitan area. See text for details. 
Table 8. Impact on Number of "HighTech" Machines Per Employee, 1993

\begin{tabular}{|c|c|c|}
\hline \multirow{3}{*}{ Controls } & \multicolumn{2}{|c|}{$\begin{array}{c}1993 \\
N=4,757\end{array}$} \\
\hline & OLS & IV \\
\hline & $(1)$ & $(2)$ \\
\hline No Controls & $\begin{array}{l}-0.09 \\
(0.03)\end{array}$ & $\begin{array}{l}-0.10 \\
(0.04)\end{array}$ \\
\hline 4-digit-industry & $\begin{array}{l}-0.05 \\
(0.03)\end{array}$ & $\begin{array}{l}-0.09 \\
(0.04)\end{array}$ \\
\hline $\begin{array}{l}\text { 4-digit-industry } \\
\text { x product price* }\end{array}$ & $\begin{array}{l}-0.03 \\
(0.02)\end{array}$ & $\begin{array}{l}-0.06 \\
(0.03)\end{array}$ \\
\hline $\begin{array}{l}\text { 4-digit industry, } \\
\text { plant sz polynm** }\end{array}$ & $\begin{array}{l}-0.07 \\
(0.03)\end{array}$ & $\begin{array}{l}-0.09 \\
(0.04)\end{array}$ \\
\hline $\begin{array}{l}\text { Previous }+ \text { other }^{* * *} \\
\text { controls. }\end{array}$ & $\begin{array}{l}-0.04 \\
(0.03)\end{array}$ & $\begin{array}{l}-0.06 \\
(0.04)\end{array}$ \\
\hline $\begin{array}{l}\text { Previous + Military } \\
\text { Contractor Controls }\end{array}$ & $\begin{array}{l}-0.04 \\
(0.03)\end{array}$ & $\begin{array}{l}-0.06 \\
(0.04)\end{array}$ \\
\hline $\begin{array}{l}\text { Previous + Exporter, } \\
\text { Foreign Ownership }\end{array}$ & $\begin{array}{l}-0.04 \\
(0.03)\end{array}$ & $\begin{array}{l}-0.07 \\
(0.04)\end{array}$ \\
\hline $\begin{array}{l}\text { Previous + Training } \\
\text { and R\&D }\end{array}$ & $\begin{array}{l}-0.04 \\
(0.03)\end{array}$ & $\begin{array}{l}-0.06 \\
(0.04)\end{array}$ \\
\hline $\begin{array}{l}\text { Dependent variable is a count of } \\
\text { where machines include CAD/C } \\
\text { machines, marterials working las } \\
\text { robots, programmable controller } \\
\text { factory floor. }{ }^{*},{ }^{* \star},{ }^{* \star *} \text { See Table } \\
\text { within metropolitan area. See te }\end{array}$ & $\begin{array}{l}\text { puters } \\
\text { lard err } \\
\text { ils. }\end{array}$ & $\begin{array}{l}\text { employee, } \\
\text { olled } \\
\text { other } \\
\text { ontrol on } \\
\text { t to clustering }\end{array}$ \\
\hline
\end{tabular}




\section{Table 9. Impact on Log Book Value of Machinery Per Employee, 1987 and 1992}

\begin{tabular}{|c|c|c|c|c|}
\hline \multirow{3}{*}{ Controls } & \multicolumn{2}{|c|}{$\begin{array}{c}1987 \\
N=6,571\end{array}$} & \multicolumn{2}{|c|}{$\begin{array}{c}1992 \\
N=4,757\end{array}$} \\
\hline & OLS & IV & OLS & IV \\
\hline & $(1)$ & (2) & (3) & (4) \\
\hline No Controls & $\begin{array}{l}-0.73 \\
(0.22)\end{array}$ & $\begin{array}{l}-1.12 \\
(0.29)\end{array}$ & $\begin{array}{l}-0.63 \\
(0.18)\end{array}$ & $\begin{array}{l}-0.60 \\
(0.22)\end{array}$ \\
\hline 4-digit-industry & $\begin{array}{l}-0.48 \\
(0.16)\end{array}$ & $\begin{array}{l}-0.71 \\
(0.21)\end{array}$ & $\begin{array}{l}-0.51 \\
(0.15)\end{array}$ & $\begin{array}{l}-0.61 \\
(0.18)\end{array}$ \\
\hline $\begin{array}{l}\text { 4-digit-industry } \\
\text { x product price* }\end{array}$ & $\begin{array}{l}-0.52 \\
(0.15)\end{array}$ & $\begin{array}{l}-0.74 \\
(0.20)\end{array}$ & $\begin{array}{l}-0.47 \\
(0.15)\end{array}$ & $\begin{array}{l}-0.52 \\
(0.18)\end{array}$ \\
\hline $\begin{array}{l}\text { 4-digit industry, } \\
\text { plant sz polynm** }\end{array}$ & $\begin{array}{l}-0.34 \\
(0.16)\end{array}$ & $\begin{array}{l}-0.47 \\
(0.21)\end{array}$ & $\begin{array}{l}-0.33 \\
(0.13)\end{array}$ & $\begin{array}{l}-0.44 \\
(0.17)\end{array}$ \\
\hline $\begin{array}{l}\text { Previous }+ \text { other }^{* * *} \\
\text { controls. }\end{array}$ & $\begin{array}{l}-0.31 \\
(0.15)\end{array}$ & $\begin{array}{l}-0.44 \\
(0.20)\end{array}$ & $\begin{array}{l}-0.28 \\
(0.13)\end{array}$ & $\begin{array}{l}-0.39 \\
(0.17)\end{array}$ \\
\hline $\begin{array}{l}\text { Previous + Military } \\
\text { Contractor Controls }\end{array}$ & $\begin{array}{l}-0.34 \\
(0.15)\end{array}$ & $\begin{array}{l}-0.49 \\
(0.20)\end{array}$ & $\begin{array}{l}-0.31 \\
(0.13)\end{array}$ & $\begin{array}{l}-0.42 \\
(0.17)\end{array}$ \\
\hline $\begin{array}{l}\text { Previous + No. of } \\
\text { technologies in use }\end{array}$ & $\begin{array}{l}-0.26 \\
(0.14)\end{array}$ & $\begin{array}{l}-0.39 \\
(0.19)\end{array}$ & $\begin{array}{l}-0.23 \\
(0.13)\end{array}$ & $\begin{array}{l}-0.31 \\
(0.17)\end{array}$ \\
\hline
\end{tabular}

Dependent variable is the book value of machinery per employee constructed using the 1987 and 1992 Census of Manufactures. ${ }^{*},{ }^{* *},{ }^{* \star *}$ See Table 7. Standard errors robust to clustering within metropolitan area. See text for details. 
Table 10. First Stage Regressions for Alternative Skill Groups

\begin{tabular}{|c|c|c|c|c|c|c|}
\hline & \multicolumn{3}{|c|}{1988 Education Shares } & \multicolumn{3}{|c|}{1993 Education Shares } \\
\hline & $\begin{array}{c}\text { High } \\
\text { School }\end{array}$ & $\begin{array}{c}\text { Some } \\
\text { College }\end{array}$ & $\begin{array}{c}\text { Four-Year } \\
\text { College }\end{array}$ & $\begin{array}{c}\text { High } \\
\text { School }\end{array}$ & $\begin{array}{c}\text { Some } \\
\text { College }\end{array}$ & $\begin{array}{c}\text { Four-Year } \\
\text { College }\end{array}$ \\
\hline $\begin{array}{l}\text { High School Shr, } \\
\text { "Predicted" Imms }\end{array}$ & $\begin{array}{c}1.28 \\
(0.40)\end{array}$ & $\begin{array}{l}-1.24 \\
(0.20)\end{array}$ & $\begin{array}{l}-0.22 \\
(0.44)\end{array}$ & $\begin{array}{l}1.77 \\
(0.67)\end{array}$ & $\begin{array}{l}-2.58 \\
(0.42)\end{array}$ & $\begin{array}{c}0.43 \\
(0.75)\end{array}$ \\
\hline $\begin{array}{l}\text { Some College Shr, } \\
\text { "Predicted" Imms }\end{array}$ & $\begin{array}{l}-0.30 \\
(0.35)\end{array}$ & $\begin{array}{c}0.44 \\
(0.17)\end{array}$ & $\begin{array}{c}0.32 \\
(0.38)\end{array}$ & $\begin{array}{l}-0.44 \\
(0.38)\end{array}$ & $\begin{array}{c}0.85 \\
(0.23)\end{array}$ & $\begin{array}{l}-0.04 \\
(0.42)\end{array}$ \\
\hline $\begin{array}{l}\text { 4-Year College Shr } \\
\text { "Predicted" Imms }\end{array}$ & $\begin{array}{c}0.43 \\
(0.12)\end{array}$ & $\begin{array}{l}-0.18 \\
(0.06)\end{array}$ & $\begin{array}{l}-0.19 \\
(0.13)\end{array}$ & $\begin{array}{c}0.54 \\
(0.14)\end{array}$ & $\begin{array}{l}-0.42 \\
(0.09)\end{array}$ & $\begin{array}{c}0.04 \\
(0.16)\end{array}$ \\
\hline Land-Grant College & $\begin{array}{l}-0.02 \\
(0.01)\end{array}$ & $\begin{array}{l}-0.01 \\
(0.01)\end{array}$ & $\begin{array}{c}0.05 \\
(0.01)\end{array}$ & $\begin{array}{l}-0.02 \\
(0.01)\end{array}$ & $\begin{array}{l}-0.01 \\
(0.01)\end{array}$ & $\begin{array}{c}0.05 \\
(0.01)\end{array}$ \\
\hline $\begin{array}{l}\mathrm{R}^{2} \\
\text { F-Stat }\end{array}$ & $\begin{array}{l}0.36 \\
19.5\end{array}$ & $\begin{array}{l}0.39 \\
22.5\end{array}$ & $\begin{array}{c}0.11 \\
4.1\end{array}$ & $\begin{array}{l}0.33 \\
17.1\end{array}$ & $\begin{array}{l}0.30 \\
145\end{array}$ & $\begin{array}{c}0.11 \\
41\end{array}$ \\
\hline & 19.5 & $2<.5$ & & & & \\
\hline
\end{tabular}

Regressions weighted by employment in SMT industries, measured using 1988 or 1993 County Business Patterns county summary files. 


\section{Table 11. The Impact of Highly Educated Relative Labor Supply of Number of Technologies}

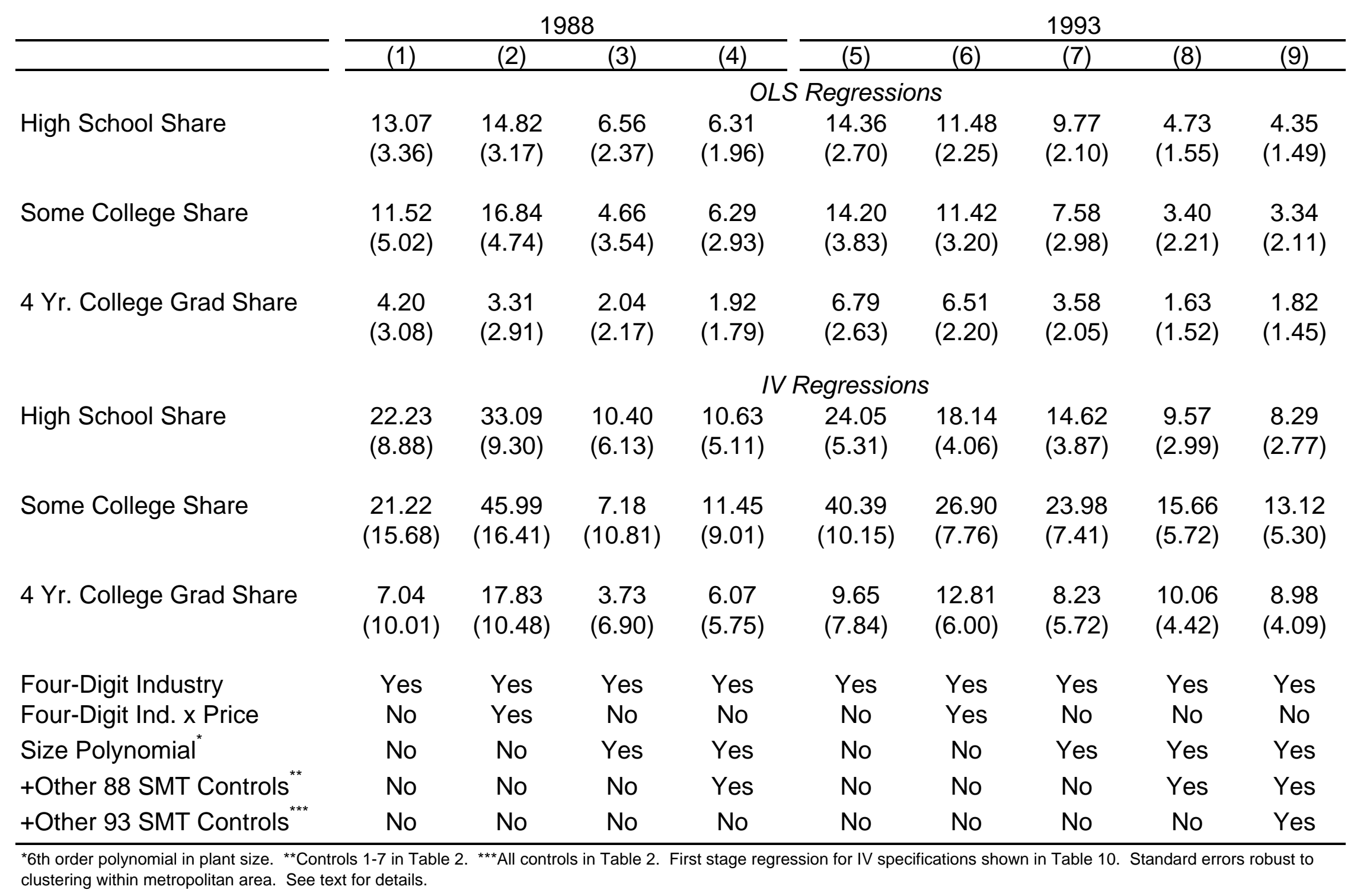




\section{Table 12. Impact of Change in Dropout/HS Eqivalent on Change in Number of Technologies, 1988-93}

\begin{tabular}{|c|c|c|}
\hline \multirow[b]{2}{*}{ Controls } & \multicolumn{2}{|c|}{$(\mathrm{N}=1,474)$} \\
\hline & OLS & IV \\
\hline & (1) & (2) \\
\hline No Controls & $\begin{array}{l}-2.93 \\
(3.79)\end{array}$ & $\begin{array}{l}-3.93 \\
(7.45)\end{array}$ \\
\hline $\begin{array}{l}\text { \# of Technologies in } \\
\text { Use, } 1988\end{array}$ & $\begin{array}{l}-4.77 \\
(2.75)\end{array}$ & $\begin{array}{l}-5.55 \\
(4.45)\end{array}$ \\
\hline $\begin{array}{l}\text { +4-digit Industry, } \\
1988\end{array}$ & $\begin{array}{l}-2.48 \\
(2.76)\end{array}$ & $\begin{array}{l}-8.52 \\
(5.32)\end{array}$ \\
\hline $\begin{array}{r}\text { +4-digit Industry, } \\
1988 \text { and } 1993\end{array}$ & $\begin{array}{l}-3.67 \\
(2.37)\end{array}$ & $\begin{array}{l}-9.97 \\
(5.02)\end{array}$ \\
\hline $\begin{array}{l}\text { Previous + \#Techs } \\
\text { planned, } 1988\end{array}$ & $\begin{array}{l}-4.48 \\
(2.54)\end{array}$ & $\begin{array}{l}-11.08 \\
(5.27)\end{array}$ \\
\hline $\begin{array}{l}\text { Previous + Plant Size } \\
\text { Polynomial }^{*}\end{array}$ & $\begin{array}{l}-3.96 \\
(2.33)\end{array}$ & $\begin{array}{l}-10.46 \\
(4.71)\end{array}$ \\
\hline $\begin{array}{l}\text { Previous + Other } \\
\text { Baseline Controls }\end{array}$ & $\begin{array}{l}-3.00 \\
(2.22)\end{array}$ & $\begin{array}{l}-10.59 \\
(4.87)\end{array}$ \\
\hline
\end{tabular}

* 6th order polynomial in 1988 plant employment. Instrument is predicted high school share dropout among immigrants who arrived in the U.S. 1988-93, predicted with 1970 metro area locations of

immigrants from 16 world regions. Standard errors robust to clustering within metropolitan area. See text for details. 


\section{Figure 1. Graphical Depiction of the Model}

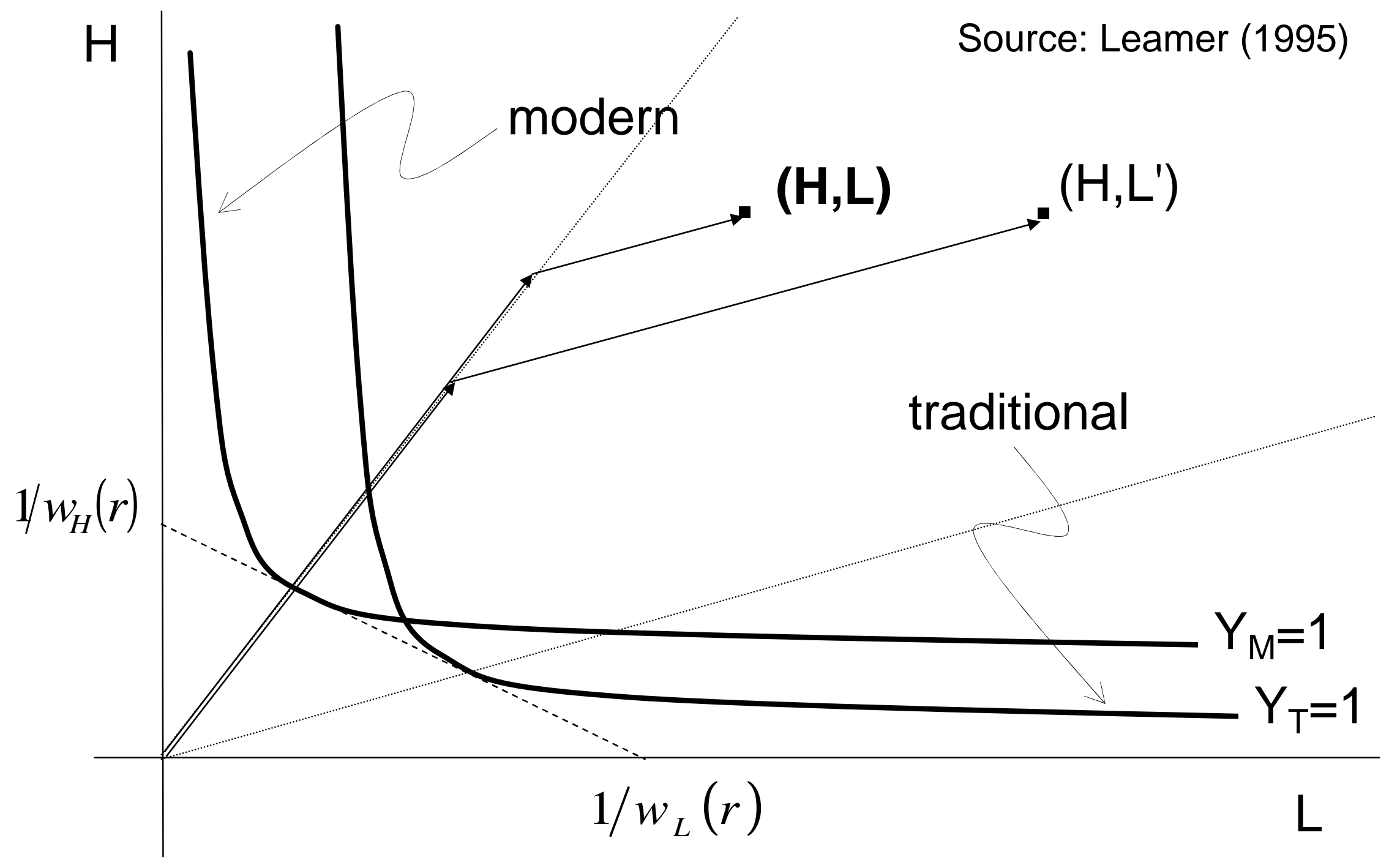


Figure 2. Dropouts/High School Equivalent in SMT industries vs. Labor Force

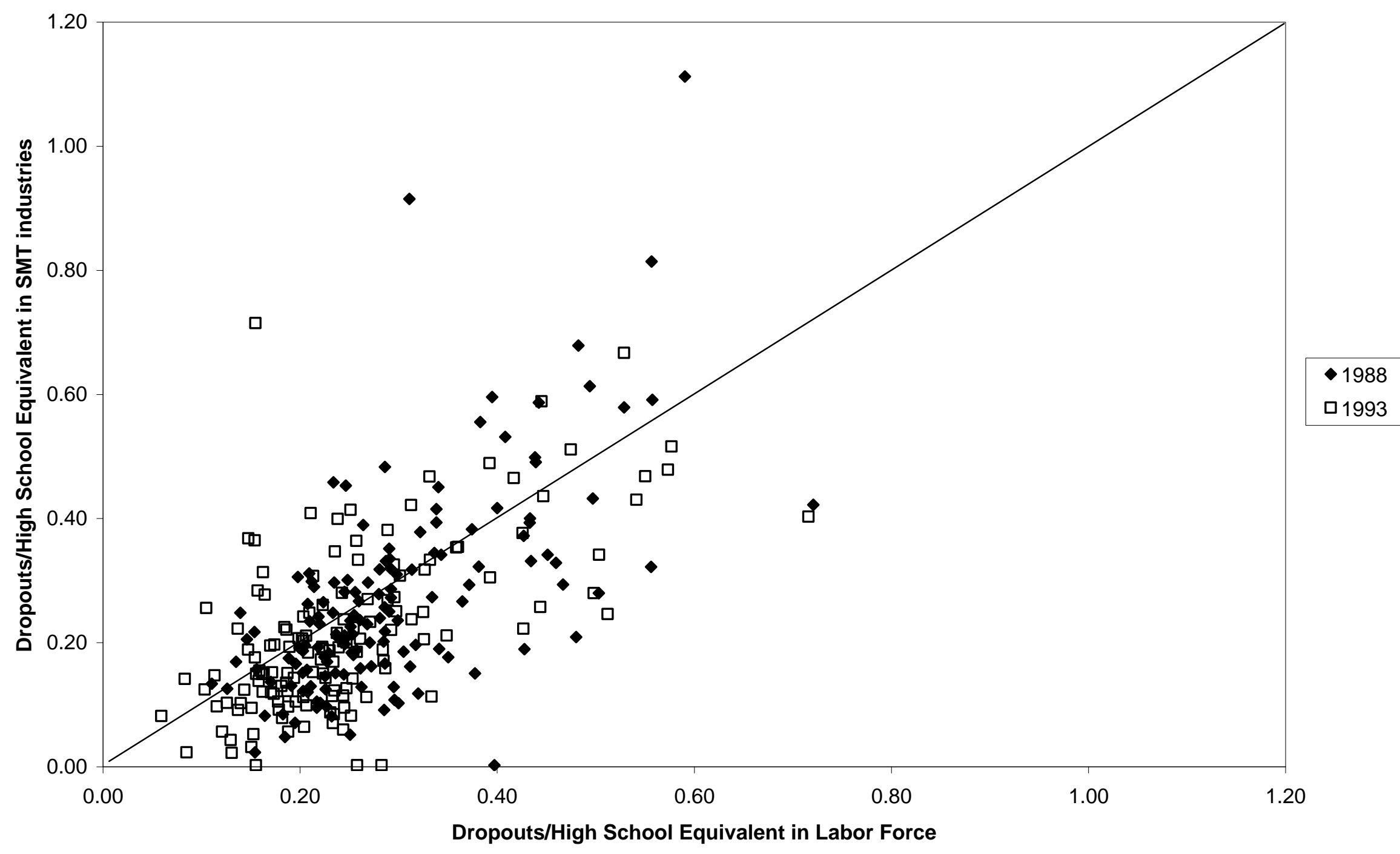




\section{Appendix Table A1. Impact of Overall Dropout Share on the Number of Technologies in Use, 1988 and 1993}

\begin{tabular}{|c|c|c|c|c|}
\hline \multirow[b]{2}{*}{ Controls } & \multicolumn{2}{|c|}{$\begin{array}{c}1988 \\
N=6,571\end{array}$} & \multicolumn{2}{|c|}{$\begin{array}{c}1993 \\
N=4,757\end{array}$} \\
\hline & OLS & IV & OLS & IV \\
\hline & (1) & (2) & (3) & (4) \\
\hline No Controls & $\begin{array}{r}-10.30 \\
(3.40)\end{array}$ & $\begin{array}{c}-13.09 \\
(7.65)\end{array}$ & $\begin{array}{l}-9.92 \\
(2.78)\end{array}$ & $\begin{array}{l}-8.04 \\
(4.57)\end{array}$ \\
\hline 4-digit-industry & $\begin{array}{l}-7.14 \\
(3.10)\end{array}$ & $\begin{array}{l}-25.63 \\
(7.81)\end{array}$ & $\begin{array}{r}-10.45 \\
(2.52)\end{array}$ & $\begin{array}{r}-15.13 \\
(4.18)\end{array}$ \\
\hline $\begin{array}{l}\text { 4-digit-industry } \\
\text { x product price* }\end{array}$ & $\begin{array}{l}-7.17 \\
(3.05)\end{array}$ & $\begin{array}{l}-24.49 \\
(7.61)\end{array}$ & $\begin{array}{l}-8.92 \\
(2.07)\end{array}$ & $\begin{array}{l}-13.63 \\
(3.45)\end{array}$ \\
\hline $\begin{array}{l}\text { 4-digit industry, } \\
\text { plant sz polynm* }\end{array}$ & $\begin{array}{l}-3.52 \\
(2.15)\end{array}$ & $\begin{array}{r}-14.37 \\
(5.24)\end{array}$ & $\begin{array}{l}-6.45 \\
(1.96)\end{array}$ & $\begin{array}{l}-9.86 \\
(3.25)\end{array}$ \\
\hline $\begin{array}{l}\text { Previous + other } \\
\text { baseline controls }\end{array}$ & $\begin{array}{l}-3.45 \\
(1.75)\end{array}$ & $\begin{array}{l}-9.68 \\
(4.12)\end{array}$ & $\begin{array}{l}-2.96 \\
(1.42)\end{array}$ & $\begin{array}{l}-6.60 \\
(2.38)\end{array}$ \\
\hline
\end{tabular}

${ }^{*},{ }^{* *}$ See Table 7. ${ }^{* * *}$ Controls 1-7 in Table 2. Columns (2) uses as the instrumental variable high school dropout share among "predicted" (from 1970 locations of immigrants from 16 world regions) immigrants who arrived 1980-86. Columns (4) uses as the instrumental variable high school dropout share among "predicted" immigrants who arrived 1988-93. Standard errors robust to clustering within metropolitan area. See text for details. 


\section{Appendix Table A2. The "Per Technology" Impact of Citywide Dropout/High School Equivalent on Subgroups of Technologies}

\begin{tabular}{|c|c|c|c|c|}
\hline \multirow{3}{*}{ Technology Class } & \multicolumn{2}{|c|}{$\begin{array}{c}1988 \\
N=6,571\end{array}$} & \multicolumn{2}{|c|}{$\begin{array}{c}1993 \\
N=4,757\end{array}$} \\
\hline & OLS & IV & OLS & IV \\
\hline & (1) & (2) & (3) & (4) \\
\hline All Technologies & $\begin{array}{l}-0.25 \\
(0.07)\end{array}$ & $\begin{array}{l}-0.38 \\
(0.09)\end{array}$ & $\begin{array}{c}-0.26 \\
(0.05)\end{array}$ & $\begin{array}{c}-0.31 \\
(0.07)\end{array}$ \\
\hline I. Computer aided design & $\begin{array}{l}-0.21 \\
(0.07)\end{array}$ & $\begin{array}{l}-0.35 \\
(0.10)\end{array}$ & $\begin{array}{c}-0.23 \\
(0.06)\end{array}$ & $\begin{array}{c}-0.25 \\
(0.08)\end{array}$ \\
\hline II. Fabrication \& machining & $\begin{array}{l}-0.23 \\
(0.08)\end{array}$ & $\begin{array}{l}-0.40 \\
(0.11)\end{array}$ & $\begin{array}{c}-0.22 \\
(0.06)\end{array}$ & $\begin{array}{c}-0.28 \\
(0.07)\end{array}$ \\
\hline III. Automated material handling & $\begin{array}{l}-0.25 \\
(0.08)\end{array}$ & $\begin{array}{l}-0.44 \\
(0.10)\end{array}$ & $\begin{array}{c}-0.19 \\
(0.07)\end{array}$ & $\begin{array}{c}-0.25 \\
(0.09)\end{array}$ \\
\hline IV. Automated Inspection & $\begin{array}{c}-0.26 \\
(0.10)\end{array}$ & $\begin{array}{l}-0.30 \\
(0.13)\end{array}$ & $\begin{array}{c}-0.30 \\
(0.08)\end{array}$ & $\begin{array}{l}-0.37 \\
(0.10)\end{array}$ \\
\hline V. Communication and control & $\begin{array}{l}-0.28 \\
(0.08)\end{array}$ & $\begin{array}{l}-0.39 \\
(0.10)\end{array}$ & $\begin{array}{l}-0.33 \\
(0.07)\end{array}$ & $\begin{array}{l}-0.37 \\
(0.09)\end{array}$ \\
\hline
\end{tabular}

Dependent variable is \#of technologies in use in that category divided by \#of technologies in that category (See Table 6). Columns (2) uses as the instrumental variable high school dropout share among "predicted" (from 1970 locations of immigrants from 16 world regions) immigrants who arrived 1980-86 and 1970 Mexican share. Columns (4) uses as the instrumental variable high school dropout share among "predicted" immigrants who arrived 1988-93 and 1970 Mexican share. All regressions control for four digit industry effects. Standard errors robust to clustering within metropolitan area. See text for details. 